\title{
Using zircon in mafic migmatites to disentangle complex high-grade gneiss terrains - Terrane spotting in the Lewisian complex, NW Scotland
}

\author{
Sebastian Fischer ${ }^{\mathrm{a}, *}$, Anthony R. Prave ${ }^{\mathrm{a}}$, Tim E. Johnson ${ }^{\mathrm{b}}$, Peter A. Cawood ${ }^{\mathrm{c}, \mathrm{a}}$, Chris J. Hawkesworth ${ }^{\mathrm{d}, \mathrm{a}}$, \\ Matthew S. A. Horstwood ${ }^{\mathrm{e}}$, EIMF $^{\mathrm{f}}$ \\ ${ }^{a}$ School of Earth 83 Environmental Sciences, University of St Andrews, KY16 9AL, Scotland, United Kingdom \\ ${ }^{b}$ School of Earth and Planetary Sciences, TIGeR, GPO Box U1987, Curtin University, Perth, WA 6845, Australia \\ ${ }^{c}$ School of Earth, Atmosphere 86 Environment, Monash University, Melbourne, VIC 3800, Australia \\ ${ }^{d}$ School of Earth Sciences, University of Bristol, BS8 1RJ, United Kingdom \\ ${ }^{e}$ NERC Isotope Geosciences Laboratory, BGS, Keyworth, Nottingham, NG12 5GG, United Kingdom \\ ${ }^{f}$ School of Geosciences, University of Edinburgh, EH9 3JW, United Kingdom
}

\begin{abstract}
The zircon record of complex high-grade gneiss terrains is key to interpreting their tectonothermal evolution. Typically, such studies focus on zircon-rich, felsic rocks, which commonly have a complicated (partial melting, inheritance, partial dissolution, and reprecipitation) zircon record. Here we show that metamorphosed mafic rocks and their retained partial melts (i.e. in situ leucosomes) provide a record of the evolution of crustal blocks that is simpler and easier to interpret. We apply our method to the Archaean high-grade gneisses of the iconic Lewisian complex of NW Scotland and use it to test the proposed terrane model that is based largely on zircon geochronology. Our work focusses on the mafic migmatites of the central region, where we identified the long-established metamorphic age clusters of ca. $2.75 \mathrm{Ga}$ and $2.5 \mathrm{Ga}$, as well as ca. $2.85 \mathrm{Ga}$ protolith ages. A key finding is that these ages are recognised across both putative terrane blocks of the central region previously proposed to record different tectonothermal histories. Our oldest (inherited) ages are similar to those within other blocks outside the central region. Thus, all these blocks likely share a common pre-metamorphic history, questioning the validity of the terrane model for the Lewisian complex. We demonstrate that mafic lithologies provide a powerful tool for identifying key stages in the polyphase evolution of metamorphic complexes that typify Earth's earliest rock records and offer additional context for assessing Earth's geodynamic evolution.
\end{abstract}

Keywords: zircon, mafic rocks, geochronology, Lewisian, terranes, Hf isotopes, Archaean, migmatites

\section{Introduction}

Zircon and its U-Pb-Hf-O isotopic and trace element compositions have been key to understanding crustal processes (Griffin et al., 2002; Rubatto, 2002; Valley et al., 2005) and the generation and evolution of continental crust (Condie, 1998; Wilde et al., 2001; Belousova et al., 2010; Dhuime et al., 2012). In high-grade metamorphic terranes, such as those that dominate the deeper levels of Archaean

*Corresponding author at: School of Earth \& Environmental Sciences, University of St Andrews, KY16 9AL, Scotland, United Kingdom Fischer)

Email address: sf67@st-andrews.ac.uk (Sebastian

Accepted Manuscript crust, zircon geochronology is also used to identify distinct tectonothermal events (e.g. Black et al., 1986; Kröner et al., 1989; Kelly and Harley, 2005). Felsic rather than mafic rocks are typically targeted for such studies because of their relatively high zircon abundance. However, Archaean crustal rocks commonly record complex polyphase histories. Zircon grains in felsic rocks can be complex, recording multiple phases of intracrustal magmatic processes, including fractional crystallisation, assimilation, fluid interaction, and mixing, mingling and hybridisation of primary (mantle-derived) and secondary (crust-derived) melts (Fig. 1B), followed by one or more metamorphic events (e.g. Whitehouse et al., 1999; Corfu et al., 2003). Consequently, there 

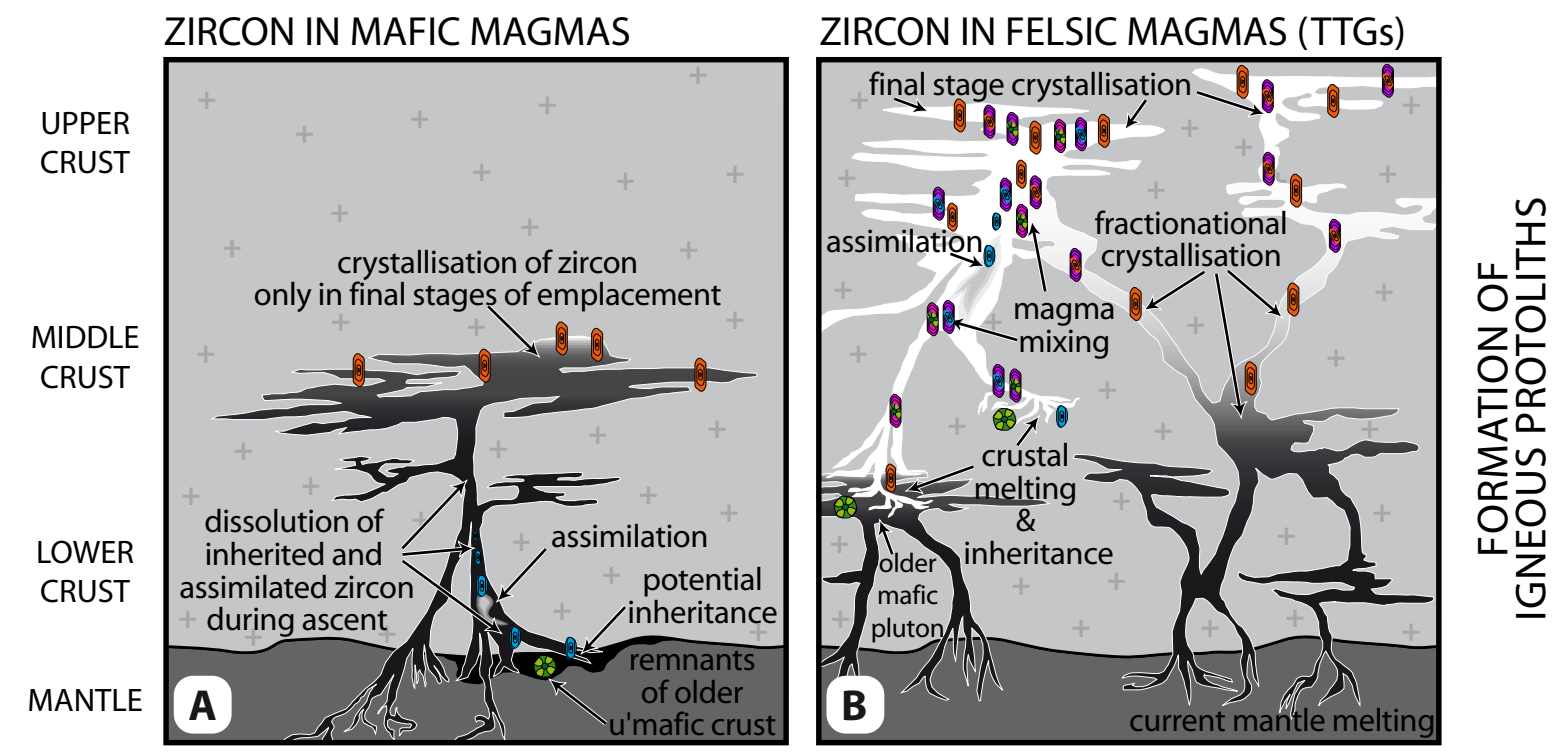

\section{TYPES OF ZIRCON}

is igneous metamorphic different igneous over- migmatitic overgrowth xenocrystic/inherited on older cores

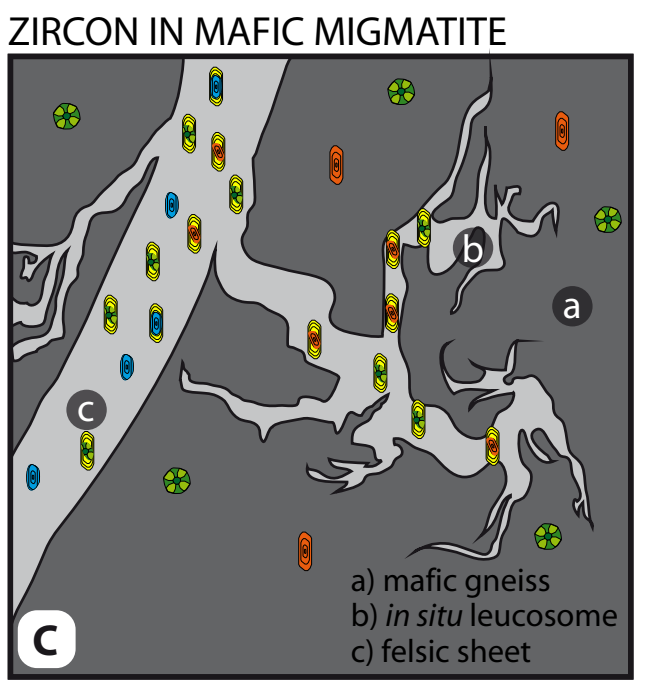

ZIRCON IN FELSIC MIGMATITE

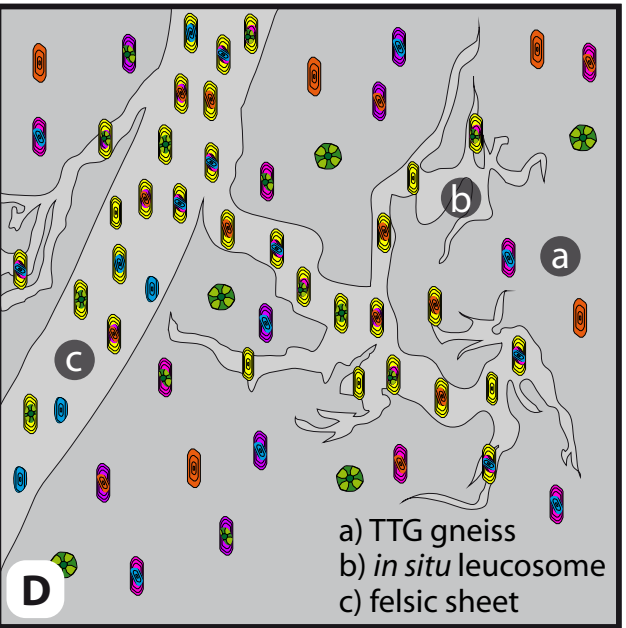

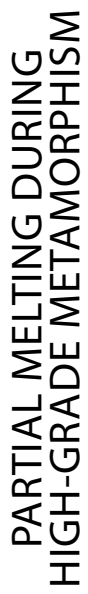
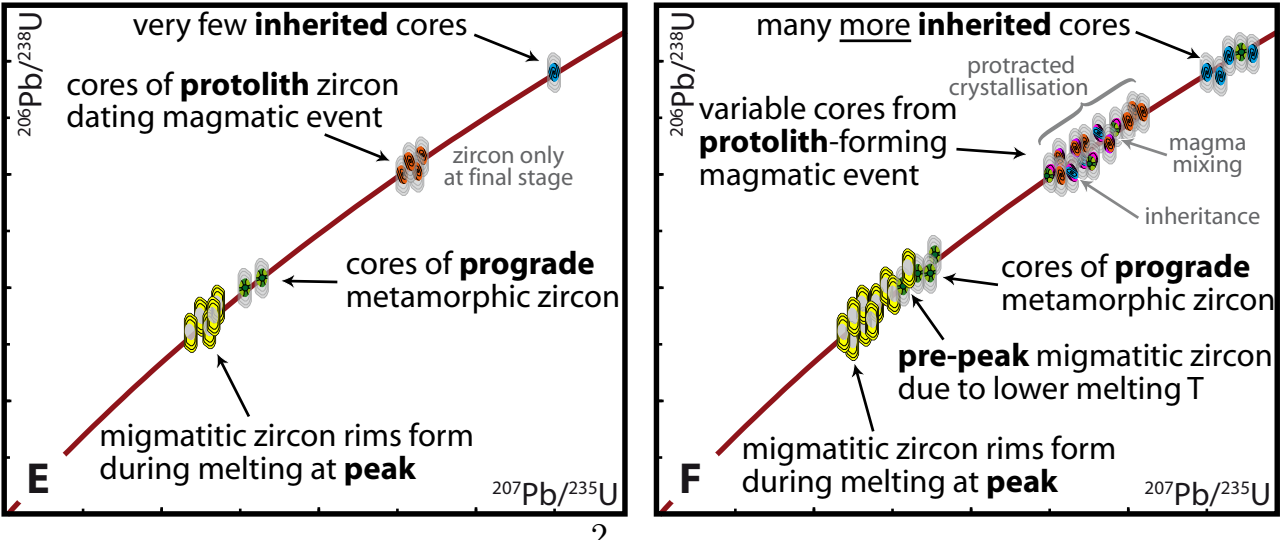

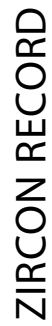


Figure 1: (Previous page.) The hypothetical zircon record in mafic vs felsic rocks. A) Mafic magmas dissolve most or all inherited and assimilated zircon due to $\mathrm{Zr}$ under-saturation. Zircon only crystallises during late stages of emplacement from interstitial melts. B) Felsic melts may entrain and retain xenocrystic zircon from their source (inheritance during partial melting of pre-existing rock or during fractionation from mafic melts) or from assimilated material, because they are typically at or close to zircon saturation. Throughout magma mixing, fractionation, and final emplacement zircon crystallises around these older or xenocrystic cores. C) Partial melting in meta-mafic rocks causes partial dissolution of zircon and re-precipitation of new zircon domains around cores of zircon from the mafic protolith. D) Partial melting in meta-felsic rocks also causes dissolution and re-precipitation. Cores contain the diverse and complex pre-existing zircon record from the felsic protolith and its preceding and assimilated zircon-bearing lithologies. E) The comparatively simple zircon record of a mafic migmatite on a hypothetical concordia, with limited or no inherited grains. Older cores date final emplacement of the mafic protolith, younger cores formed during prograde metamorphic reactions (e.g. amphibole breakdown) and rims date the leucosome crystallisation. F) The comparatively complex zircon record of a felsic migmatite on a hypothetical concordia, showing a larger spread of ages compared to the mafic migmatite (E). The spread of inherited grains stems from detrital meta-sediments and other assimilants or protoliths. Additionally, zircon forms not only at final emplacement, because felsic magmas reach zircon saturation much earlier during their evolution. Prograde metamorphism forms zircon, and during high-grade metamorphism partial melting will occur earlier and zircon will form across a longer time period.

is potential for inheritance, resorption, dissolution and/or re-precipitation of zircon (e.g. Harley et al., 2007; Fig. 1F). Taken together, these complicate the zircon record in felsic rocks from high-grade gneiss terrains, imparting a range of elemental and isotopic compositions that are difficult to disentangle and interpret.

Here, we adopt a novel approach to the study of Archaean high-grade gneiss terrains. Rather than felsic rocks, we focus on granulite facies mafic lithologies preserving evidence for partial melting (i.e. mafic migmatites, Fig. 1C). Our hypothesis is that, compared to felsic rocks, zircon grains within mafic gneisses and their in situ leucosomes have a relatively simple history, one dominated by protolith-forming magmatic crystallisation and newly grown zircon recording later highgrade metamorphic processes (Fig. 1). Most mafic magmas are mantle-derived or formed by remelting of ultramafic (i.e. zircon-free) crustal precursors (Johnson et al., 2014), and zircon in mafic magmas most likely forms during the final stages of crystallisation (Shao et al., 2018). Consequently, magmatic zircon in mafic rocks is not subject to the same complex magmatic processes or the potential for inheritance as its felsic counterpart (Fig. 1A,E).

Here, we demonstrate the utility of zircon from mafic migmatites in unravelling the geological history of high-grade gneiss terrains. Using the iconic Meso- to Neoarchaean Lewisian complex of NW Scotland as a case study, we present new zircon $\mathrm{U}-\mathrm{Pb}$ age, isotope and trace element data to assess its metamorphic evolution and interrogate the terrane model currently debated for that complex (Friend and Kinny, 2001; Love et al., 2004; Kinny et al., 2005; Park, 2005; Park et al., 2005; Corfu,
2007; Whitehouse and Kemp, 2010; Crowley et al., 2015).

\section{Geological background}

The Lewisian complex is a fragment of Archaean crust exposed on mainland Scotland (Fig. 2) and the Outer Hebrides. It comprises grey gneisses of tonalite-trondhjemite-granodiorite (TTG) composition with subordinate mafic to ultramafic gneisses and minor metasedimentary units (e.g. Peach et al., 1907; Bowes et al., 1964; Cartwright et al., 1985). The mainland complex is traditionally subdivided into amphibolite facies northern and southern regions that are separated from a granulite facies central region by major shear zones (Fig. 2). Four tectonometamorphic episodes have been identified, from older to younger: the granulite facies Badcallian event, the subsequent amphibolite and/or granulite facies Inverian event (mainly recognised along major shear zones), the intrusion of the ultramafic to mafic Scourie dyke swarm, and, lastly, the amphibolite facies Laxfordian event (e.g. Sutton and Watson, 1951; Evans, 1965; Park, 1970).

Phase equilibrium modelling has refined estimates of granulite facies peak $P-T$ to $8-10 \mathrm{kbar}$ and $>900{ }^{\circ} \mathrm{C}$ throughout the central region (Johnson and White, 2011; Feisel et al., 2018), consistent with evidence for partial melting in all lithologies except the ultramafic rocks (Johnson et al., 2012, 2013). Retrogression initially occurred during high-temperature decompression to $7-9 \mathrm{kbar}$ (Johnson and White, 2011), and $P-T$ conditions for the amphibolite facies Inverian event have been constrained to $5-6.5 \mathrm{kbar}$ and $520-550^{\circ} \mathrm{C}$ (Zirkler et al., 2012). Estimates for Laxfordian metamorphism (in the southern region around Gairloch, 


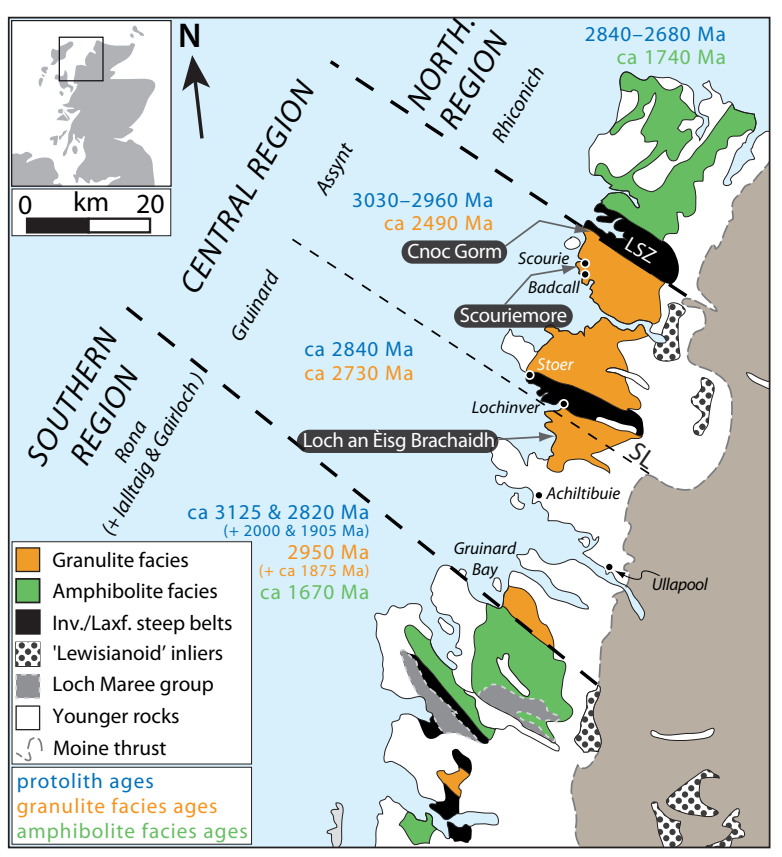

Figure 2: Simplified geological map of the mainland Lewisian complex (modified after Johnson et al., 2016). Dashed lines mark the division into northern, central and southern region (capital letters) and the proposed terranes (in italics; Kinny et al., 2005). Ages for the proposed terranes from Love et al. (2010). Locations 02, 03, 04 are at Cnoc Gorm, location 05 at Scouriemore and location 11 at Loch an Eisg Brachaidh. See text for more details. LSZ = Laxford shear zone, SL = Strathan Line

Fig. 2) are $6.5 \pm 1.5 \mathrm{kbar}$ and $530 \pm 20^{\circ} \mathrm{C}$ (Droop et al., 1999).

\subsection{Geochronology and the terrane model}

Although the Badcallian, Inverian and Laxfordian events were originally defined with reference to particular styles of deformation and metamorphism, radiometric ages have since been ascribed to each of these episodes: $2.8-2.7 \mathrm{Ga}$ and $2.49 \mathrm{Ga}$ for the Badcallian and Inverian, respectively, 2.4 and 2.0 Ga for the Scourie dykes, and 1.8-1.7 Ga for the Laxfordian (e.g. Wheeler et al., 2010; Whitehouse and Kemp, 2010; Goodenough et al., 2013; Davies and Heaman, 2014). However, interpretations of the geochronological data differ (e.g. Love et al., 2004; Corfu, 2007; Taylor et al., 2020) and, as a result, the tectonic and temporal coherence of the Lewisian complex continues to be of considerable debate.

Earlier researchers regarded the mainland Lewisian as a contiguous sliver of Archaean crust, in which different crustal levels were exhumed and juxtaposed along shear zones (e.g. Sutton and Watson, 1951; Park and Tarney, 1987). By contrast, based largely on $\mathrm{U}-\mathrm{Pb}$ zircon geochronology predominantly from TTG gneisses, an alternative view emerged: proponents regard the timing of the first high-grade metamorphism to be asynchronous and stress the presence or absence of particular protolith ages from samples from different areas. From these interpretations, they infer that the Lewisian complex comprises an amalgamation of numerous discrete crustal blocks or terranes (e.g. Kinny et al., 2005; Park, 2005). Of the proposed terrane boundaries, one subdivides the central region into the Assynt block (north) and Gruinard block (south), respectively (Love et al., 2004). However, the zircon age data typically form a smear along concordia (e.g. Whitehouse and Kemp, 2010; Goodenough et al., 2013), which is difficult to interpret, and the number of terranes, their boundaries and the history of accretion remain controversial (Kinny and Friend, 1997; Corfu et al., 1998; Friend and Kinny, 2001; Love et al., 2004; Kinny et al., 2005; Park, 2005; Park et al., 2005; Corfu, 2007; Love et al., 2010; Goodenough et al., 2010; MacDonald and Goodenough, 2013).

The terrane debate has implications for understanding not only the geodynamic setting of the Lewisian, but also the geodynamic style that operated during the Meso- to Neoarchaean. The age of the Lewisian complex (ca. 3.1-2.5 Ga) places it during the postulated transition from stagnant-lid to plate tectonics (see Hawkesworth and Brown, 2018, for an overview). The onset of plate tectonics is typically dated to ca. $3 \mathrm{Ga}$ (Cawood et al., 2006; Shirey and Richardson, 2011; Dhuime et al., 2012), followed by a transition period when both modes co-existed until plate tectonics was fully established by about ca. $2.5 \mathrm{Ga}$ (Brown, 2014). Thus, refining the geochronology of the Lewisian Complex can enhance understanding of this key period in Earth's geodynamical evolution.

\subsection{Mafic-ultramafic complexes}

Mafic and ultramafic rocks within the Lewisian complex range from centimetre- to metre-scale pods and boudins aligned parallel to the foliation to larger sheet-like bodies a hundred metres or more in width and up to two kilometres in strike length (Peach et al., 1907; Bowes et al., 1964; Rollinson and Gravestock, 2012; Johnson et al., 2016). Modal 
layering in the larger mafic-ultramafic bodies implies that they represent discrete igneous intrusions that underwent post-emplacement fractional crystallisation prior to granulite facies metamorphism (Davies, 1974; Sills et al., 1982; Johnson et al., 2012, 2016; Guice et al., 2018). In many places, the mafic-ultramafic bodies are associated with micarich rocks of possible sedimentary and/or volcanic origin (so-called brown gneisses; Cartwright et al. 1985).

The genesis and geodynamic implications of the mafic bodies are not entirely resolved; suggested models include intrusion as layered complex(es) (Bowes et al., 1964; Guice et al., 2018), intercalation of oceanic crust during subduction (Tarney and Weaver, 1987), formation at or near Earth's surface (Cartwright et al., 1985; Rollinson and Gravestock, 2012), and/or sagducted remnants of Archaean greenstone belts (Johnson et al., 2016). Moreover, it is likely that not all mafic and ultramafic bodies formed by the same process (e.g. Rollinson and Gravestock, 2012; Guice et al., 2020).

Traditionally, and based largely on field observations, the mafic bodies are thought to be older ('early basic gneisses', e.g. Goodenough et al., 2013) than the surrounding ca. 2.9 Ga TTGs (Rollinson and Windley, 1980; Park and Tarney, 1987), an inference supported by a single $\mathrm{U}-\mathrm{Pb}$ zircon age of ca. $2.96 \mathrm{Ga}$ for a felsic unit which cross-cuts one of the mafic bodies (Rollinson and Gravestock, 2012). The most widely accepted magmatic age constraints for the protoliths of the mafic gneisses are whole-rock Sm-Nd ages of $2943 \pm 91 \mathrm{Ma}$ and $2846 \pm 73 \mathrm{Ma}$ from a hornblendite at Gruinard Bay (Gruinard block; Whitehouse et al., 1996). These ages are supported by ${ }^{207} \mathrm{~Pb} /{ }^{206} \mathrm{~Pb}$ zircon data from the same locality that give an age range of $2857 \pm 25 \mathrm{Ma}$ to $2650 \pm 5 \mathrm{Ma}$ (Whitehouse et al., 1997), in which the older age might date magmatism. Corfu et al. (1998) interpret a zircon age of $2826 \mathrm{Ma}$ from this locality to date intrusion of the gabbroic protoliths. However, as all of these protolith ages stem from the same locality, and not all mafic and ultramafic bodies necessarily share the same origin (e.g. Guice et al., 2020), further estimates of protolith ages are needed. Isotope dilution analysis of $\mathrm{U}-\mathrm{Pb}$ in zircons from a mafic gneiss at Badcall (Assynt block) yielded a variety of ages, including $2711 \mathrm{Ma}$ and $2701 \mathrm{Ma}$, interpreted by the authors to date granulite facies (Badcallian) metamorphism (Corfu et al., 1994).

\section{Samples and analytical procedures}

A total of 15 samples (Table S2) of mafic gneiss, in situ leucosome, and cross-cutting felsic sheets that interconnect (and are considered to be contemporaneous) with the leucosomes were collected from three localities at Cnoc Gorm (southern part of the Laxford shear zone; Fig. 2 and 3A,B), one locality at Scouriemore (northern part of the central region, the postulated Assynt terrane; Fig. 2 and 3C) and one locality at Loch an Eisg Brachaidh (southern part of the central region, the postulated Gruinard terrane; Fig. 2 and 3D).

All samples were collected from larger, internally coherent bodies of mafic material (e.g. Johnson et al., 2012; Guice et al., 2020, also see section 2.2) rather than the lenticular pods ubiquitous in the grey gneisses (Rollinson and Gravestock, 2012) or the mafic portion of compositionally banded gneisses. The precise petrogenesis and emplacement mechanisms for the protoliths is debated (see section 2.2), but our samples of mafic gneisses are basaltic in composition (whole rock data in Supplementary Material Table S1 and Fig. S1), and are interpreted as metamorphosed gabbros (cf. Johnson et al., 2012).

These mafic gneisses, or metagabbros, typically are medium-grained amphibole-plagioclase gneisses, some with and some without garnet, and may contain accessory minerals such as titanite. They show a subtle but pervasive foliation. Their in situ leucosomes are typically coarser-grained quartzofeldspathic veins and contain large clots of amphibole (interpreted to replace peritectic pyroxene; e.g. Fig. 3a,b) and in some places garnet. They range from a few $\mathrm{mm}$ to several $\mathrm{dm}$ in width, show a mafic selvedge at the contact to their mafic host (Figure $3 a, b)$ and can often be traced to feed into larger felsic sheets, which are also quartzofeldspathic but largely lack peritectic phases. More detail on the samples is provided in Supplementary Material section 1 .

Zircons (see Supplementary Material Table S2 for more detail on zircon size, morphology and colour) were hand-picked, mounted in one-inch epoxy discs, and imaged using back-scattered electron (BSE) and cathodoluminescence (CL) techniques (Fig. 4) on a JEOL 8600 superprobe at University of St Andrews. Secondary ion mass spectrometry (SIMS) analyses were performed at the NERC Ion Microprobe Facility (EIMF, at the University of Edinburgh), using the CAMECA IMS-1270 for U-Pb 

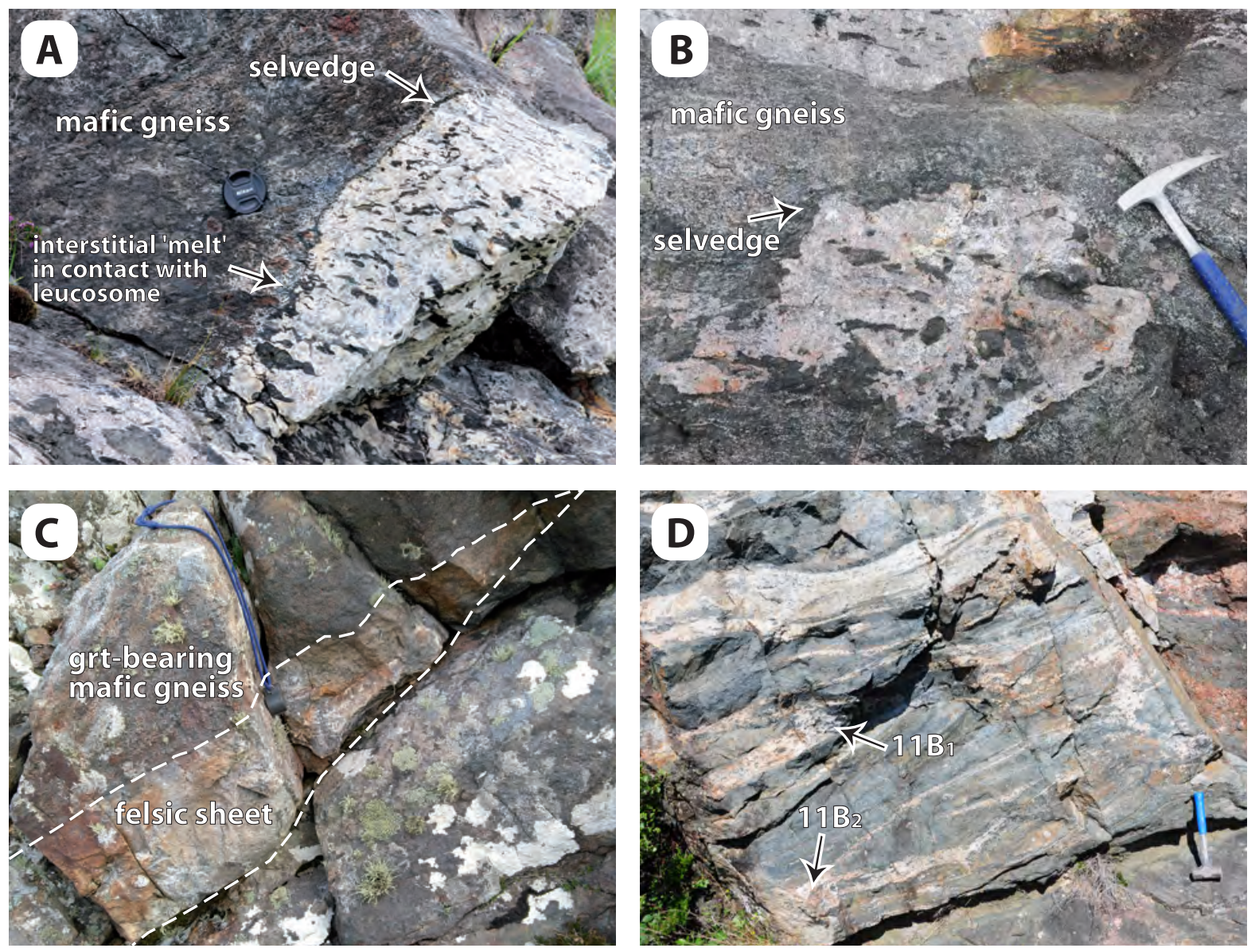

Figure 3: Photographs of field relationships. A Cnoc Gorm (loc. 02): in situ leucosome with pegmatitic texture, containing large crystals of amphibole (replacing peritectic clinopyroxene) and plagioclase (sample 02B), in contact with mafic gneiss (sample $02 \mathrm{~A}$, garnet-bearing and close to the contact; 02D without garnet, ca. $30-50 \mathrm{~cm}$ away). Note thin selvedge of hornblende at the contact as well as petrographic continuity between the pegmatitic leucosome and interstitial leucosome within the mafic gneiss. (67mm lens cap for scale) B Cnoc Gorm (loc. 03): in situ leucosome with 1-5 cm sized patches of amphibole (replacing peritectic clinopyroxene; sample 03B) again showing a selvedge of amphibole. (Hammer for scale) C Scouriemore (loc. 05): locally-derived (in source) felsic sheet (sample 05C) cutting through garnet-bearing mafic gneiss. (Hand lens is $4 \mathrm{~cm}$ thick) D Loch an Èisg Brachaidh (loc. 11): in situ leucosome and melt pool (samples 11B1 and 11B2), both in petrographic continuity with smaller-scale interstitial leucosome. (Hammer for scale $36 \mathrm{~cm}$ long).

dating, followed by trace element analysis on the CAMECA IMS-4f. Hf isotopes were analysed using a New Wave Research UP193FX excimer laser ablation unit attached to a ThermoScientific Neptune Plus MC-ICP-MS at the NERC Isotope Geoscience Laboratory (NIGL), Keyworth. Analyses of unknowns and standards were performed on the exact same spot or, where impossible, within the same growth zone as identified by CL/BSE imaging. Analytical procedures and conditions are outlined in Supplementary Material S2.

\section{Results}

\subsection{Zircon geochronology}

After initial screening of data for discordance, high ${ }^{204} \mathrm{~Pb}$ contents, and comparison of calculated vs. measured ${ }^{208} \mathrm{~Pb} /{ }^{206} \mathrm{~Pb}$ ratios (see Supplementary Material S3), clusters of ages were identified and weighted average, concordia or discordia intercept ages calculated. Outliers were omitted when calculating a combined age, as discussed in Supplementary Material S3. Unless noted, uncertainties in 


\section{Cnoc Gorm}

mafic gneiss
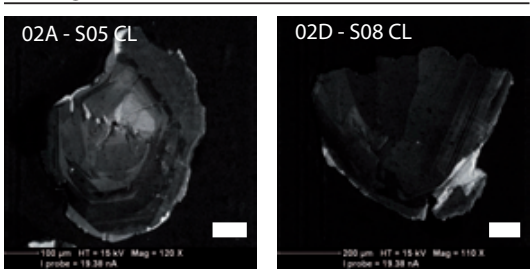

Cnoc Gorm

large felsic sheet
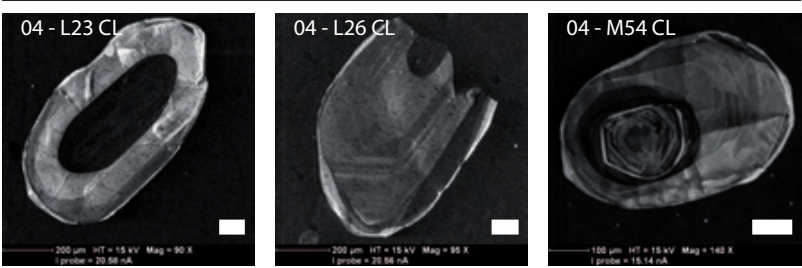
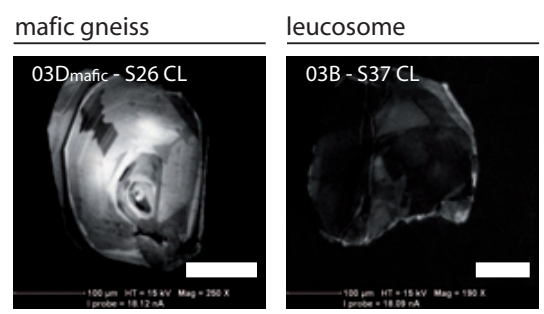

Scouriemore

leucosome

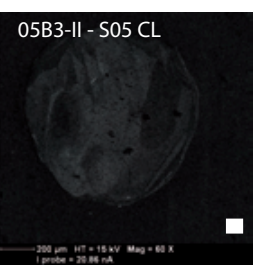

Loch an Èisg Brachaidh

mafic gneiss
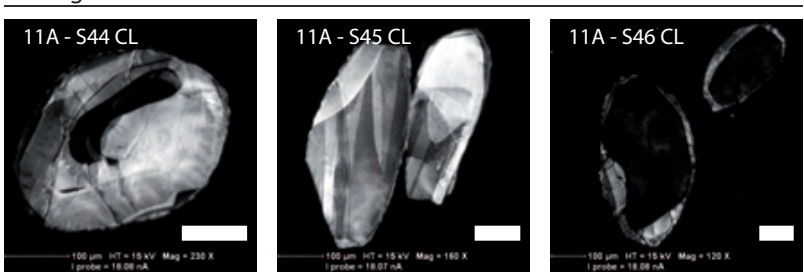

mafic gneiss (amphibolite)

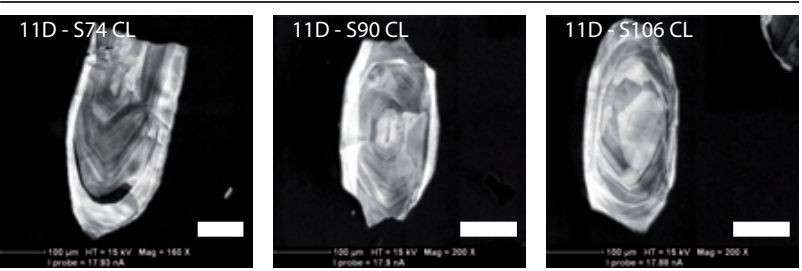

Loch an Èisg Brachaidh

leucosome
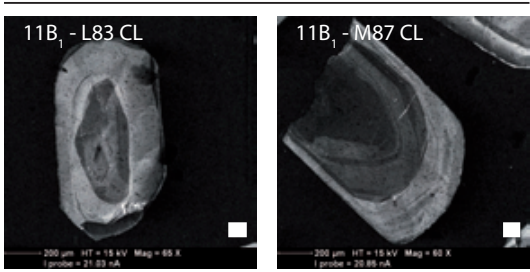
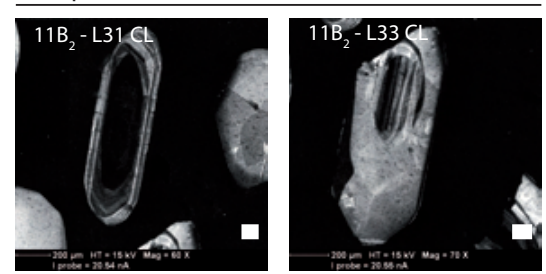

felsic sheet
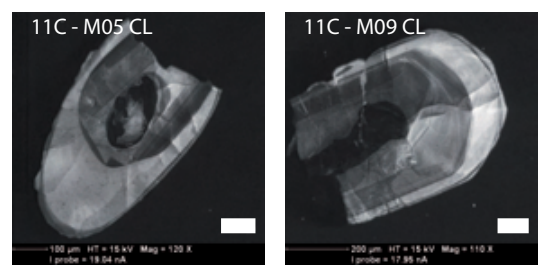

Figure 4: Cathodoluminescence images of exemplary zircons, illustrating the complex zonation patterns; white bars at the bottom left of each image are $100 \mu \mathrm{m}$ wide.

the text are $95 \%$ confidence intervals. An overview of our interpreted ages is given in Table 1 .

\subsubsection{Cnoc Gorm (S part of Laxford shear zone)}

At the first Cnoc Gorm locality, two mafic gneisses (samples 02A, 02D) and an in situ leucosome (sample 02B) yielded zircon. Zircons from sample $02 \mathrm{~A}$ (Fig. S3) yielded a concordia age of $2491.4 \pm 10.0 \mathrm{Ma}(\mathrm{n}=5, \mathrm{MSWD}=2.4)$ from dates on ten core analyses. Six dates from rims give a concordia age of $2484 \pm 10 \mathrm{Ma}(\mathrm{n}=5$, MSWD $=2.5$ ) and an unzoned grain gave two dates of
$2479 \pm 6 \mathrm{Ma}$ and $2488 \pm 8 \mathrm{Ma}$. Since all dates are identical within error, combining all data yields a concordia age of $2483.7 \pm 6.9 \mathrm{Ma}(\mathrm{n}=12$, MSWD $=1.6$; Fig. 5A). Sample 02D only yielded one zircon grain with a core age of $2458 \pm 8 \mathrm{Ma}(\mathrm{n}=2)$ and a rim age of $2444 \pm 4 \mathrm{Ma}$.

Leucosome sample 02B (Fig. S3) has a concordia age of $2491.9 \pm 7.8 \mathrm{Ma}(\mathrm{n}=9, \mathrm{MSWD}=1.9)$ based on ten dates on cores, whereas the rims had four analyses with a concordia age of $2492.2 \pm 8.4 \mathrm{Ma}$ $(\mathrm{n}=4, \mathrm{MSWD}=1.06)$. Two analyses are notably younger $(1818 \pm 48 \mathrm{Ma}$ and $1778 \pm 32 \mathrm{Ma})$. Again, 

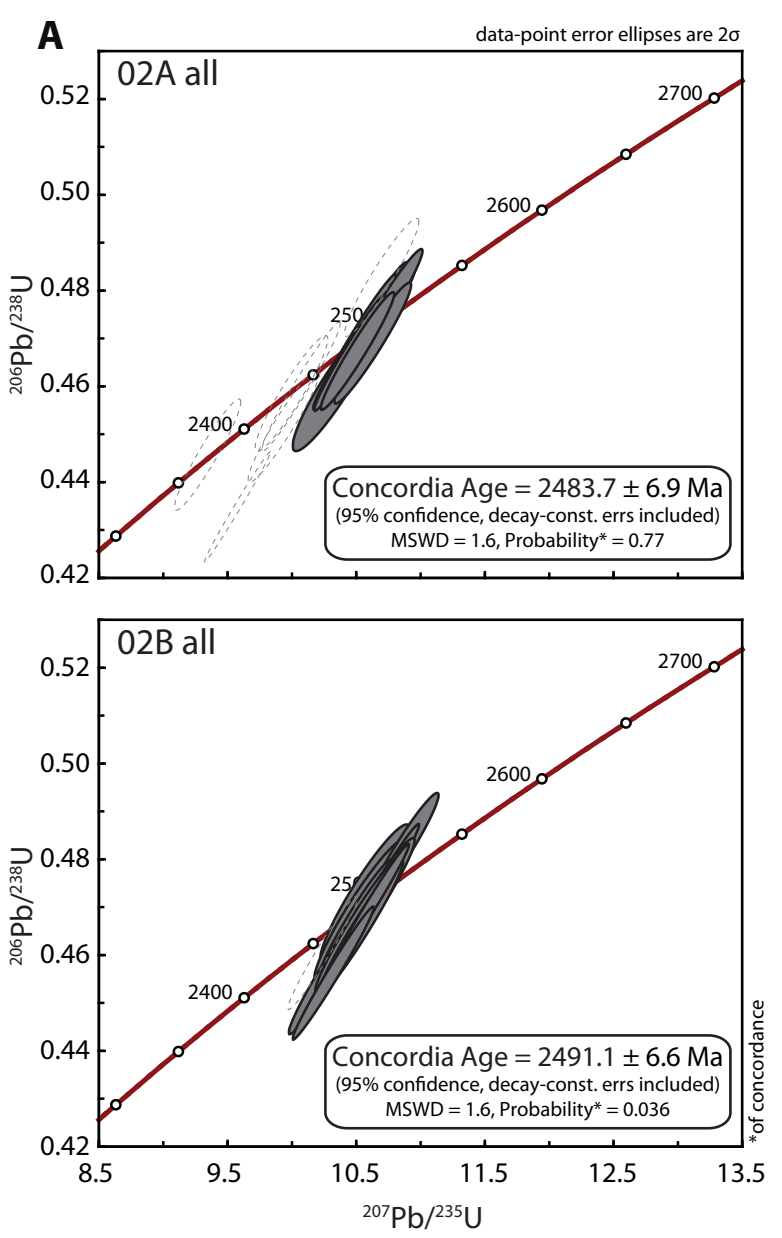

B

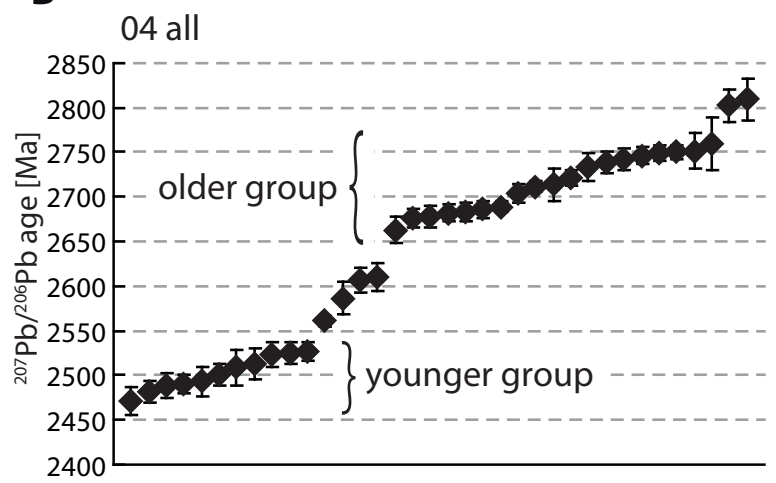

data-point error ellipses are $2 \sigma$

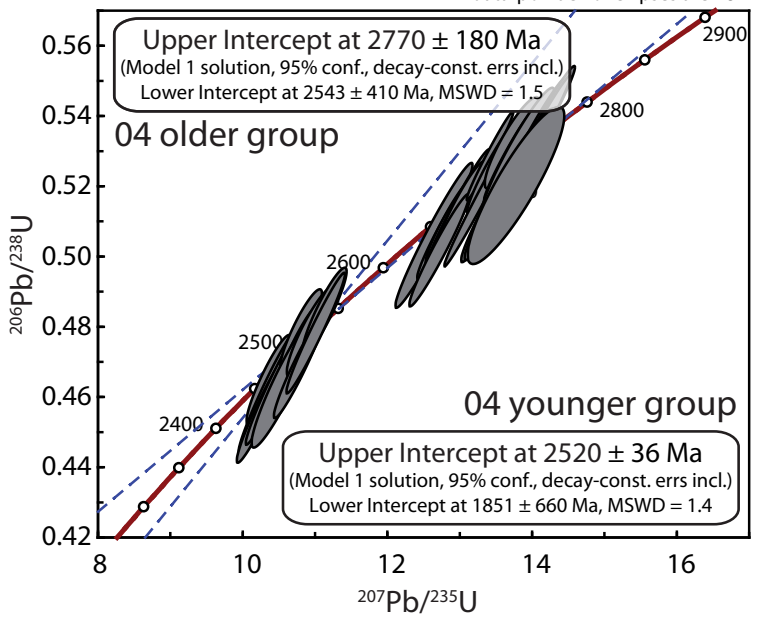

Figure 5: A) Concordia diagrams for mafic gneiss (02A) and leucosome (02B) from the first locality at Cnoc Gorm. For concordia plots and age calculations some data have been omitted; these are noted on the diagram as dashed ellipses. B) Two age groups can be identified in the felsic sheet (sample 04) at Cnoc Gorm. A plot of all zircon ${ }^{207} \mathrm{~Pb} /{ }^{206} \mathrm{~Pb}$ ages in ascending order (top) shows the two groups that appear to form continuous series, interrupted by an abrupt jump. Error bars are at $2 \sigma$. For both groups, discordia ages (bottom) can be calculated.

the ages of core and older rim populations are identical within uncertainty and give a combined concordia age of $2491.1 \pm 6.6 \mathrm{Ma}(\mathrm{n}=13$, MSWD $=1.6$, Fig. 5A).

At the second locality a leucosome (sample 03B) and a mafic gneiss (sample 03D) contained zircon (Fig. S4). In the mafic gneiss, 13 analyses were obtained across all domains. Unzoned grains and some cores comprise a group with a concordia age of $2475.0 \pm 6.9 \mathrm{Ma}(2 \sigma, \mathrm{n}=3, \mathrm{MSWD}=0.44)$, whereas the rims and the other cores yielded two groups with concordia ages at $1820 \pm 25 \mathrm{Ma}(\mathrm{n}=$ $3, \mathrm{MSWD}=0.98)$ and $1770.3 \pm 5.7 \mathrm{Ma}(2 \sigma, \mathrm{n}=5$, MSWD $=0.98)$, respectively.
In the leucosome (03B), only one grain showed a core-rim zonation with a ${ }^{207} \mathrm{~Pb} /{ }^{206} \mathrm{~Pb}$ age of $2595 \pm 74 \mathrm{Ma}$ for the core and $2521 \pm 8 \mathrm{Ma}$ for the rim. Ten analyses on unzoned grains gave a concordia age of $2495.6 \pm 9.9 \mathrm{Ma}(\mathrm{n}=6$, MSWD $=2.3$ ), and one much younger date at $1754 \pm 8 \mathrm{Ma}$.

The third locality is a large felsic sheet that crosscuts the hill and extends laterally for several hundred metres. One sample (04) yielded eight dates from zircon cores, 11 from intermediate zones, 16 from rims and one from an unzoned grain. There is no apparent correlation between age and domain, but two age trends are present (Fig. 5B), one around $2500 \mathrm{Ma}$ and another around $2700 \mathrm{Ma}$. 
The younger cluster (2527-2471 Ma) defines a discordia with an upper intercept at $2520 \pm 36 \mathrm{Ma}$ and a lower intercept at $1851 \pm 660 \mathrm{Ma}(\mathrm{n}=11$, MSWD = 1.4) whereas the older cluster (2759$2663 \mathrm{Ma}$ ) defines a discordia with an upper intercept at $2770 \pm 180 \mathrm{Ma}$ and a lower intercept at $2543 \pm 410 \mathrm{Ma}(\mathrm{n}=19$, MSWD $=1.5$, Fig. 5B). In both cases, although associated with large uncertainties, the intercept ages are similar to ages reported from elsewhere in the Lewisian complex (e.g. Corfu et al., 1994; Zhu et al., 1997; Kinny and Friend, 1997; Love et al., 2004), and are probably meaningful.

\subsubsection{Scouriemore (Assynt block)}

Three leucosomes (samples 05B1+2, 05B3-I, 05B3-II) and a $20 \mathrm{~cm}$ wide, cross-cutting felsic sheet (sample 05C) yielded zircons (Fig. 6).

In sample $05 \mathrm{~B} 1+2,13$ dates from cores define a concordia age of $2747.8 \pm 8.5 \mathrm{Ma}(\mathrm{n}=6, \mathrm{MSWD}=$ 1.3). Nine dates on rims span from 2731-2473 Ma, and only concordia-parallel discordia with intercept ages that vary by more than $200 \mathrm{Ma}$ can be calculated. Hence, meaningful ages are difficult to extract. For sample 05B3-I, six dates from cores, six from rims and 17 from unzoned zircons yield a total range of dates from $2873-2477 \mathrm{Ma}$ with no systematic pattern between age and domain, although a small cluster defines a concordia age of $2515.7 \pm 9.7 \mathrm{Ma}(\mathrm{n}=5, \mathrm{MSWD}=1.8)$. For sample 05B3-II, four dates from cores, four from intermediate zones, nine from rims, and eight from unzoned grains span ages from 2813-2489 Ma. Again, there is no apparent clustering or systematic relationship between domain and age, thus no combined age can be calculated for this sample.

In the felsic sheet (sample 05C), seven dates were obtained from cores and 14 from rims. All analyses span a near-continuous spectrum of ages from 2939 to $2499 \mathrm{Ma}$, with a conspicuous absence of dates between 2696 and $2575 \mathrm{Ma}$. Similar age gaps are observed in all samples (Fig. 6).

\subsubsection{Loch an Èisg Brachaidh (Gruinard block)}

Two mafic gneisses (samples 11A, 11D; Fig. S5) and three felsic rocks (leucosome $11 \mathrm{~B}_{1}$, felsic pod $11 \mathrm{~B}_{2}$, felsic sheet $11 \mathrm{C}$; Fig. S6) were sampled at this locality. In mafic gneiss sample $11 \mathrm{~A}$ (Fig. 7), two dates were obtained from a core, two from a rim and 10 from unzoned grains, yielding two age clusters: one at ca. $2500 \mathrm{Ma}$ with a concordia age of $2515.6 \pm 12.0 \mathrm{Ma}(\mathrm{n}=6, \mathrm{MSWD}=1.9)$, and one

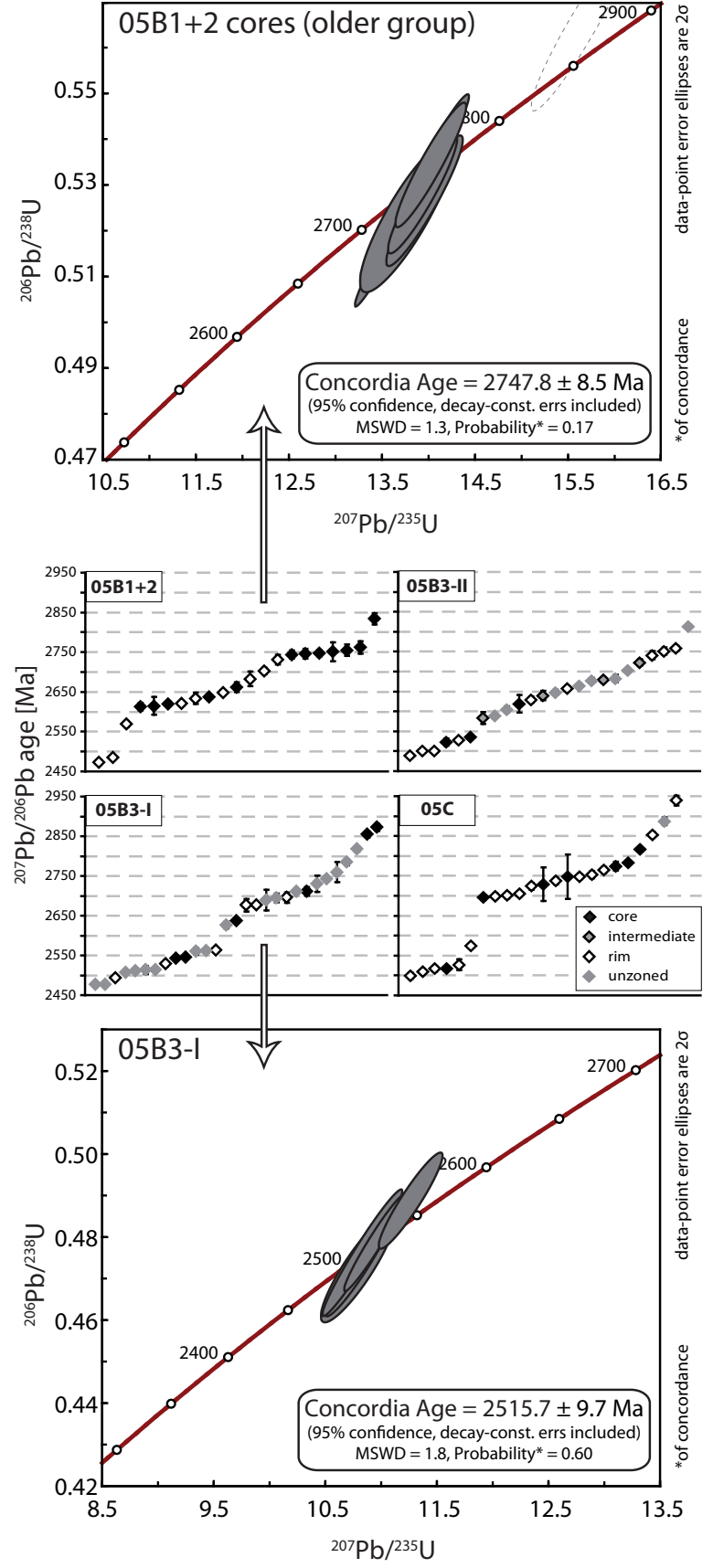

Figure 6: Plots of all zircon ${ }^{207} \mathrm{~Pb} /{ }^{206} \mathrm{~Pb}$ ages in Scouriemore leucosome samples 05B1+2, 05B3-I, 05B3-II and felsic sheet sample $05 \mathrm{C}$ (centre). Error bars are $2 \sigma$ (in most cases less than the symbol size). Concordia ages can be calculated for samples 05B1+2 (top) and 05B3-I (bottom).

at ca. $2750 \mathrm{Ma}$, defining a discordia with an upper intercept age of $2755.1 \pm 8.8 \mathrm{Ma}(\mathrm{n}=6, \mathrm{MSWD}=$ $1.5)$ and a lower intercept at $232 \pm 510 \mathrm{Ma}$. An- 

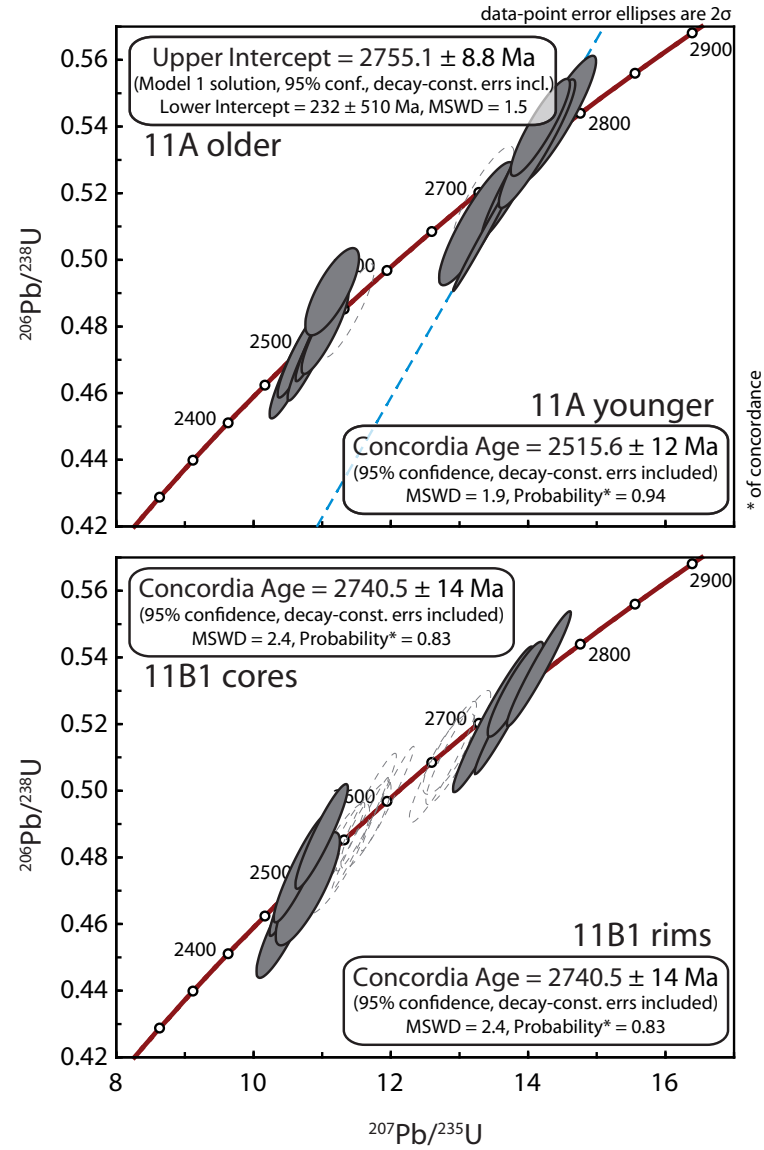

Figure 7: Calculated population ages for Loch an Èisg Brachaidh mafic sample 11A (top) and leucosome sample 11B1 (bottom).

choring the discordia at either present day or a Grampian age ( $470 \mathrm{Ma})$ gives, within uncertainty, the same upper intercept ages. Notably, one unzoned grain has an age of $2756 \pm 20 \mathrm{Ma}$ at its centre and $2521 \pm 14 \mathrm{Ma}$ towards the edge.

In the other mafic gneiss sample 11D (Fig. S5), 16 dates were obtained from cores, three from intermediate zones, ten from rims and one unzoned grain with two dates of $3027 \pm 24 \mathrm{Ma}$ and $2530 \pm 10 \mathrm{Ma}$, respectively. The younger rims and the younger date from the unzoned grain define a discordia with an upper intercept age of $2520 \pm 15 \mathrm{Ma}(\mathrm{n}=5, \mathrm{MSWD}=2.5$, lower intercept at $1088 \pm 440 \mathrm{Ma}$ ). Of the remaining data, eight are similar in ${ }^{207} \mathrm{~Pb} /{ }^{206} \mathrm{~Pb}$ age and define a concordia age of $2768.1 \pm 6.7 \mathrm{Ma}(\mathrm{n}=8, \mathrm{MSWD}=1.17)$.

Leucosome sample $11 \mathrm{~B}_{1}$ (Fig. 7) has seven dates from cores that define a concordia age of
Table 1: Summary of zircon population ages of this study

\begin{tabular}{|c|c|c|c|}
\hline $\begin{array}{l}\text { sample } \\
\text { rock type }\end{array}$ & population & Age & (n, MSWD) \\
\hline \multicolumn{4}{|l|}{ Cnoc Gorm } \\
\hline $\begin{array}{l}\text {..02A } \\
\text { mafic gneiss }\end{array}$ & $\begin{array}{l}\text { cores } \\
\text { rims } \\
\text { all }\end{array}$ & $\begin{array}{l}2491 \pm 10 \mathrm{Ma} \\
2484 \pm 10 \mathrm{Ma} \\
2484 \pm 7 \mathrm{Ma}\end{array}$ & $\begin{array}{l}(5,2.4) \\
(5,2.5) \\
(12,1.6)\end{array}$ \\
\hline $\begin{array}{l}\text {...02B } \\
\text { leucosome }\end{array}$ & $\begin{array}{l}\text { cores } \\
\text { rims } \\
\text { all }\end{array}$ & $\begin{array}{l}2492 \pm 8 \mathrm{Ma} \\
2492 \pm 8 \mathrm{Ma}^{a} \\
2491 \pm 7 \mathrm{Ma}\end{array}$ & $\begin{array}{l}(9,1.9) \\
(4,1.06) \\
(12,1.6)\end{array}$ \\
\hline $\begin{array}{l}\text {...02D } \\
\text { mafic gneiss }\end{array}$ & $\begin{array}{l}\text { core } \\
\text { rim }\end{array}$ & $\begin{array}{l}2458 \pm 8 \mathrm{Ma}^{b} \\
2444 \pm 4 \mathrm{Ma}^{c}\end{array}$ & \\
\hline $\begin{array}{l}\text {...03B } \\
\text { leucosome }\end{array}$ & unzoned & $2496 \pm 10 \mathrm{Ma}^{d}$ & \\
\hline $\begin{array}{l}\text {..03D } \\
\text { mafic gneiss }\end{array}$ & $\begin{array}{l}\text { older } \\
\text { younger }\end{array}$ & $\begin{array}{l}2475 \pm 7 \mathrm{Ma}^{e} \\
1820 \pm 25 \mathrm{Ma} \\
1770 \pm 6 \mathrm{Ma}\end{array}$ & $\begin{array}{l}(3,0.44) \\
(3,0.98) \\
(5,0.98)\end{array}$ \\
\hline $\begin{array}{l}\text {...04 } \\
\text { felsic sheet }\end{array}$ & $\begin{array}{l}\text { older } \\
\text { younger }\end{array}$ & $\begin{array}{l}2770 \pm 170 \mathrm{Ma}^{*} \\
2520 \pm 36 \mathrm{Ma}^{*}\end{array}$ & $\begin{array}{l}(19,1.5) \\
(11,1.4)\end{array}$ \\
\hline Scouriemore & & & \\
\hline $\begin{array}{l}\ldots 05 \mathrm{~B}_{1+2} \\
\text { leucosome }\end{array}$ & older & $2748 \pm 9 \mathrm{Ma}$ & $(6,1.3)$ \\
\hline $\begin{array}{l}\text {...05B3-I } \\
\text { leucosome }\end{array}$ & younger & $2516 \pm 10 \mathrm{Ma}$ & $(5,1.8)$ \\
\hline Loch an Èis & Brachaidh & & \\
\hline $\begin{array}{l}\text {...11A } \\
\text { mafic gneiss }\end{array}$ & $\begin{array}{l}\text { older } \\
\text { younger }\end{array}$ & $\begin{array}{l}2755 \pm 9 \mathrm{Ma}^{* f} \\
2516 \pm 12 \mathrm{Ma}^{g}\end{array}$ & $\begin{array}{l}(6,1.5) \\
(6,1.9)\end{array}$ \\
\hline $\begin{array}{l}\text {...11D } \\
\text { mafic gneiss }\end{array}$ & $\begin{array}{l}\text { older } \\
\text { younger }\end{array}$ & $\begin{array}{l}2768 \pm 7 \mathrm{Ma} \\
2520 \pm 15 \mathrm{Ma}^{*}\end{array}$ & $\begin{array}{l}(8,1.7) \\
(5,2.5)\end{array}$ \\
\hline $\begin{array}{l}\ldots 11 \mathrm{~B}_{1} \\
\text { leucosome }\end{array}$ & $\begin{array}{l}\text { cores } \\
\text { rims }\end{array}$ & $\begin{array}{l}2741 \pm 14 \mathrm{Ma} \\
2496 \pm 12 \mathrm{Ma}\end{array}$ & $\begin{array}{l}(4,2.4) \\
(6,2.0)\end{array}$ \\
\hline $\begin{array}{l}11 \mathrm{~B}_{2} \\
\text { melt pod }\end{array}$ & $\begin{array}{l}\text { cores } \\
\text { rims }\end{array}$ & $\begin{array}{l}2733 \pm 21 \mathrm{Ma} \\
2502 \pm 10 \mathrm{Ma}\end{array}$ & $\begin{array}{l}(3,2.1) \\
(8,1.5)\end{array}$ \\
\hline $\begin{array}{l}\ldots 11 \mathrm{C} \\
\text { felsic sheet }\end{array}$ & $\begin{array}{l}\text { unzoned } \\
\text { rims }\end{array}$ & $\begin{array}{l}2724 \pm 16 \mathrm{Ma}^{*} \\
2510 \pm 22 \mathrm{Ma}^{*}\end{array}$ & $\begin{array}{l}(4,2.9) \\
(7,1.16)\end{array}$ \\
\hline
\end{tabular}

* denotes upper intercept age, all others are concordia ages.

${ }^{a}$ two rims of $1818 \mathrm{Ma} \& 1778 \mathrm{Ma}$

${ }^{b}$ two spots on same core

${ }^{c}$ single spot on rim

$d$ one age of $1754 \pm 8 \mathrm{Ma}$

e contains only cores

$f 2756 \mathrm{Ma}$ (unzoned grain - centre)

g $2521 \mathrm{Ma}$ (unzoned grain - edge)

$2740.5 \pm 14.0 \mathrm{Ma}(\mathrm{n}=4, \quad \mathrm{MSWD}=2.4)$ and 12 dates from rims with a concordia age of $2496.3 \pm 12.0 \mathrm{Ma}(\mathrm{n}=6, \quad \mathrm{MSWD}=2.0)$. One 
date from an intermediate zone is significantly older $(3079 \pm 30 \mathrm{Ma})$, but is $11 \%$ discordant. The former melt pod sample $11 \mathrm{~B}_{2}$ has five dates from cores that define a concordia age of $2733 \pm 21 \mathrm{Ma}(\mathrm{n}=$ 3 , MSWD $=2.1$; Fig. S6). One core and one intermediate zone have significantly older ages of $2854 \pm 16 \mathrm{Ma}$ and $2809 \pm 8 \mathrm{Ma}$, respectively. Nine dates from rims, combined with two more intermediate zones of similar age, define a concordia age of $2501.8 \pm 10.0 \mathrm{Ma}(\mathrm{n}=8, \mathrm{MSWD}=1.5)$.

In felsic sheet sample $11 \mathrm{C}$, one $11.4 \%$ discordant date on a core and three from intermediate zones (two are $10 \%$ and $5.5 \%$ discordant) define a discordia (Fig. S6) with an upper intercept age of $2724 \pm 16 \mathrm{Ma}(\mathrm{n}=4, \mathrm{MSWD}=2.9$; lower intercept at $264 \pm 260 \mathrm{Ma})$ or $2735 \pm 19 \mathrm{Ma}(\mathrm{MSWD}=2.6)$ when anchored at a $470 \mathrm{Ma}$ Grampian age. Two other analyses from intermediate zones are much older at $2897 \pm 16 \mathrm{Ma}$ and $3149 \pm 14 \mathrm{Ma}$, the latter $(8.1 \%$ discordant $)$ is the oldest date obtained in this study. Two further dates from an intermediate zone are much younger at $2543 \pm 12 \mathrm{Ma}$ and $2527 \pm 12 \mathrm{Ma}$. Seven of the nine dates from rims fall on a discordia line, with an upper intercept age of $2510 \pm 22 \mathrm{Ma}(\mathrm{n}=7, \mathrm{MSWD}=1.16$, lower intercept at $709 \pm 250 \mathrm{Ma})$ or $2494.5 \pm 10.0 \mathrm{Ma}$ when anchored at $470 \mathrm{Ma}$. The other two rims are older at $2936 \pm 22 \mathrm{Ma}$ and $2628 \pm 16 \mathrm{Ma}$.

\subsection{Zircon Hf isotopic composition}

\subsubsection{Cnoc Gorm (S part of Laxford shear zone)}

The Hf isotopic composition of zircons from Cnoc Gorm samples are shown in Fig. 8 (top panel). At the first sample locality, both mafic gneisses (samples 02A, 02D) have similar Hf isotopic compositions with ${ }^{176} \mathrm{Hf} /{ }^{177} \mathrm{Hf}_{\mathrm{i}}$ of 0.280998 $0.281048(\epsilon \mathrm{Hf}=-9.5$ to -2.7$)$ and $0.281046-$ 0.281068 ( -6.7 to -4.9$)$, respectively. Most leucosome grains (sample 02B) are of identical composition at $0.281028-0.281088(-5.53$ to -3.2$)$, but two younger rim analyses are significantly more radiogenic at 0.281462 and $0.281557(-5.8$ and -3.3$)$.

At the second sample locality, the older zircon domains in the mafic gneiss (sample 03D) have Hf isotope ratios indistinguishable from zircon in the mafic gneisses at the first locality, with ${ }^{176} \mathrm{Hf} /{ }^{177} \mathrm{Hf}_{\mathrm{i}}$ of $0.280993-0.281060(-7.1$ to -4.2$)$. The younger domains (all rims and a few of the cores) are again more radiogenic and show a larger range in values at $0.281412-0.281607(-7.2$ to -1.7$)$. In the leucosome (sample 03B), the older analyses are identical to the mafic gneisses from both localities,
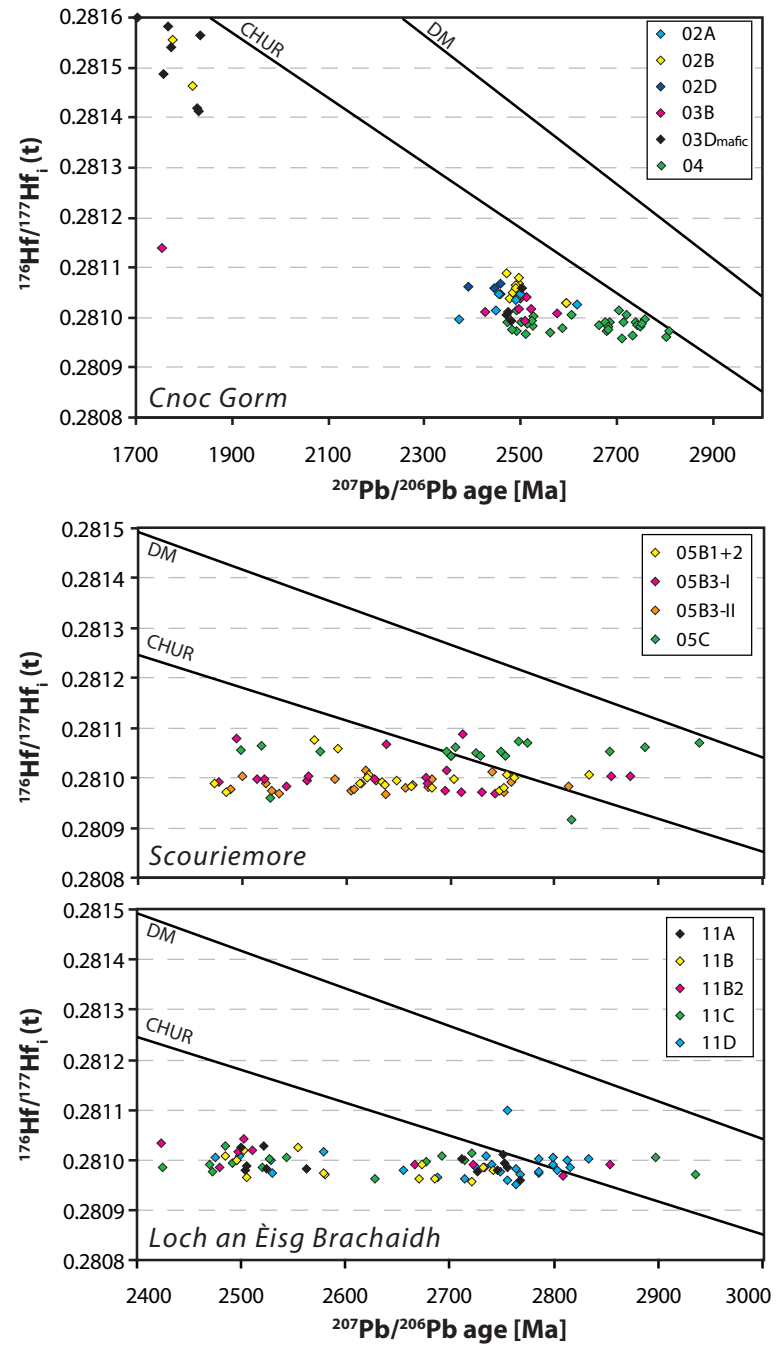

Figure 8: ${ }^{176} \mathrm{Hf} /{ }^{177} \mathrm{Hf}_{\mathrm{i}}$ vs. ${ }^{207} \mathrm{~Pb} /{ }^{206} \mathrm{~Pb}$ age for zircons from all samples; Cnoc Gorm (top), Scouriemore (middle), and Loch an Èisg Brachaidh (bottom). No differentiation was made between different zircon growth domains, since there is no clear systematic pattern. Note change in scale between Cnoc Gorm and the other two localities.

with ${ }^{176} \mathrm{Hf} /{ }^{177} \mathrm{Hf}_{\mathrm{i}}$ of $0.280992-0.281040(-7.7$ to -3.1 ). One younger analysis on an unzoned grain is slightly more radiogenic $(0.281138$ or -18.8$)$, but differs significantly from the other younger Cnoc Gorm analyses.

In the large felsic sheet (sample 04), zircons have a fairly consistent Hf isotopic composition of $0.280958-0.281013$ (mean of $0.280984 \pm 0.000014$ ) over their entire age range from 2809-2471 Ma with near-chondritic values in the oldest grains $(\epsilon \mathrm{Hf}=$ -7.7 to -0.1$)$. 


\subsubsection{Scouriemore (Assynt block)}

All leucosome zircons (samples 05B1+2, 05B3$\mathrm{I}$ and $05 \mathrm{~B} 3-\mathrm{II})$ have similar ${ }^{176} \mathrm{Hf} /{ }^{177} \mathrm{Hf}_{\mathrm{i}}$ values (Fig. 8, middle panel) between 0.280968-0.281014 (mean $=0.280989 \pm 0.000013)$, with five slightly more radiogenic analyses (up to 0.281088 ), and they are virtually constant across the entire age range of 2873-2478 Ma. In the felsic sheet (sample 05C), zircons show an equally constant, but slightly more radiogenic, Hf isotopic composition of $0.281043-$ 0.281073 (mean $=0.281055 \pm 0.000010$ ) across their entire age range (2939-2499 Ma). Two analyses are less radiogenic (0.280916 and 0.280960). The difference between the mean values from leucosomes and felsic sheet equates to about two $\epsilon \mathrm{Hf}$ units. Notably, the outliers (more radiogenic in the leucosomes and less radiogenic in the felsic sheet) fall in the range of the respective other sample (Fig. 8).

\subsubsection{Loch an Èisg Brachaidh (Gruinard block)}

These samples form a horizontal trend (Fig. 8, bottom panel) on a plot of ${ }^{176} \mathrm{Hf} /{ }^{177} \mathrm{Hf}_{\mathrm{i}}$ vs. ${ }^{207} \mathrm{~Pb} /{ }^{206} \mathrm{~Pb}$ age (i.e. have a constant ${ }^{176} \mathrm{Hf} /{ }^{177} \mathrm{Hf}_{\mathrm{i}}$ composition). The whole sample set, with the exception of a more radiogenic core in mafic gneiss sample 11D, is indistinguishable from the Scouriemore leucosome with ${ }^{176} \mathrm{Hf} /{ }^{177} \mathrm{Hf}_{\mathrm{i}}$ of $0.280949-0.281042$ and a mean of $0.280992 \pm 0.000023$.

\subsection{Ti-in-zircon thermometry}

Zircon crystallisation temperatures $\left(T_{\text {zirc }}\right)$ based on the Ti concentration as analysed by SIMS were calculated using the calibration of Ferry and Watson (2007). Due to the absence of rutile in all but one sample (i.e. $\alpha_{\mathrm{TiO}_{2}}<1$ ), all temperatures are minima and have an estimated uncertainty of ca $50{ }^{\circ} \mathrm{C}$ (see Supplementary Material S4). Almost all samples have $T_{\text {zirc }}$ values of $750-850{ }^{\circ} \mathrm{C}$ (Fig. S7). Notably, at Cnoc Gorm several zircons show significantly lower $T_{\text {zirc }}$ of less than $600{ }^{\circ} \mathrm{C}$, all of which correspond to grains with younger ages (1800-1700 Ma). In the felsic sheet (sample 05C) at Scouriemore, in particular the older (inherited?) zircon domains record slightly lower $T_{\text {zirc }}$ of 700 $800^{\circ} \mathrm{C}$. The amphibolite (sample 11D) at Loch an Èisg Brachaidh also records lower $T_{\text {zirc }}(650-$ $700{ }^{\circ} \mathrm{C}$ ), but this may be due to a lack of quartz (i.e. $\alpha_{\mathrm{SiO}_{2}}<1$ ).

\section{Discussion}

\subsection{Hf isotopes}

Two broad groups of ${ }^{176} \mathrm{Hf} /{ }^{177} \mathrm{Hf}_{\mathrm{i}}$ can be recognised in the Archaean zircons (Fig. 8): (i) 0.28095-0.28105, defined by the felsic sheet at Cnoc Gorm, the leucosomes at Scouriemore and all samples at Loch an Eisg Brachaidh, and (ii) 0.28100-0.28110, which typifies the remaining samples. Whitehouse and Kemp (2010) report identical values from two associated tonalite gneisses and also note the constancy of Hf isotopic composition across all ${ }^{207} \mathrm{~Pb} /{ }^{206} \mathrm{~Pb}$ ages. This consistency in ${ }^{176} \mathrm{Hf} /{ }^{177} \mathrm{Hf}_{\mathrm{i}}$, as indicated by horizontal arrays in Fig. 8, is indicative of variable $\mathrm{Pb}$-loss (i.e. partial resetting of the $\mathrm{U}-\mathrm{Pb}$ clock) during recrystallisation and/or dissolution and re-precipitation, without any significant exchange of $\mathrm{Hf}$ (i.e. incorporation of more radiogenic Hf) with the surrounding rock (e.g. Gerdes and Zeh, 2009; Whitehouse and Kemp, 2010; O'Brien and Miller, 2014). This variable resetting, due to one or more episodes of high-grade metamorphism, also explains typical data from Lewisian zircons that 'smear' along concordia (Whitehouse and Kemp, 2010; Goodenough et al., 2013).

The younger, 1800-1700 Ma analyses in mafic gneisses and leucosomes (rims and a few cores from samples 03D and 02B) from Cnoc Gorm (located within the Laxford shear zone) have more radiogenic Hf isotopic compositions. Thus, their composition cannot be explained by $\mathrm{Pb}$-loss alone but must reflect incorporation of more radiogenic $\mathrm{Hf}$ from the surrounding rock at the time of their formation. Using the ${ }^{176} \mathrm{Lu} /{ }^{177} \mathrm{Hf}$ bulk rock ratio of sample $02 \mathrm{~B}(0.0220)$ to calculate a Hf isotope evolution line reproduces the appropriate compositions at around $1800 \mathrm{Ga}$. This ${ }^{176} \mathrm{Lu} /{ }^{177} \mathrm{Hf}$ value, albeit somewhat high for a felsic rock, is typical for mafic (Archaean) crust (e.g. Whitehouse and Kemp, 2010; Dhuime et al., 2012).

\subsection{Ages}

Many of the Lewisian samples show a smear of near-concordant to concordant dates along the concordia line, a feature common to samples from the Lewisian complex (Kinny and Friend, 1997; Love et al., 2004; Whitehouse and Kemp, 2010; Goodenough et al., 2013; Taylor et al., 2020). Evidence from Hf isotope data (see above) suggests that this is a result of variable ancient Pb-loss. Thus, the 
upper-end of a smear would represent the date with little or no Pb-loss and, hence, the best estimate for the age of an event before the $\mathrm{U}-\mathrm{Pb}$ system was disturbed by later (tectonothermal) processes.

Plots of ${ }^{207} \mathrm{~Pb} /{ }^{206} \mathrm{~Pb}$ ages sorted in ascending order (e.g. Fig. 6) show ramps and flats, the former defined by very few ages and the latter where many analyses fall. Ages older than $2.8 \mathrm{Ga}$ are rare and are considered to reflect magmatic crystallisation (protolith) ages (in the case of the mafic gneisses) or inheritance from their source rocks (in the case of the leucosomes and felsic sheets). The flats generally occur at 2800-2700 Ma and ca. $2500 \mathrm{Ma}$ and are considered to be related to discrete tectonothermal events, reflecting effective resetting and/or new growth of zircon at those times. Since cores and rims of similar age are intermingled, we suggest that much of the data reflect variable resetting of individual domains.

The three metamorphic episodes inferred from the zircon age data correspond to the wellestablished metamorphic episodes in the Lewisian complex (Fig. 9): the older metamorphic event, dated at around 2.8-2.7 Ga, corresponds to the first granulite facies event, the Badcallian. The second high-grade event, at around $2.5 \mathrm{Ga}$, we relate to the Inverian episode. The younger clusters at around $1.8 \mathrm{Ga}$ are interpreted to be related to the Laxfordian episode.

The gneisses and leucosomes within the southern part of the Laxford shear zone (at Cnoc Gorm) contain relatively well-defined populations at ca. 2.492.48 Ga and ca. $1.8-1.7 \mathrm{Ga}$ (i.e. Inverian and Laxfordian), respectively (Fig. 9, Table 1). Only two analyses had an older ${ }^{207} \mathrm{~Pb} /{ }^{206} \mathrm{~Pb}$ age of ca. $2.62 \mathrm{Ga}$, which we interpret as incomplete resetting of older (perhaps Badcallian) zircon (also see Taylor et al., 2020). These findings are consistent with previous interpretations of the Laxford shear zone as one of the structures that localised overprinting during the Inverian (Evans, 1965; Zirkler et al., 2012) and reactivated during the Laxfordian (Goodenough et al., 2010).

Zircons from the Assynt block (Scouriemore samples) show the most pronounced smear along concordia. Badcallian ages are represented by the dominant age of ca. $2.75 \mathrm{Ga}$, either as concordia age (sample $05 \mathrm{~B} 1+2)$ and/or as the upper end of the age array (the other samples). The single $2516 \mathrm{Ma}$ population age and the lower end of the age arrays at 2.5-2.47 Ga are, within uncertainty, typical In- verian ages. The oldest ages after the gap in the zircon age array (i.e. ca. $2550 \mathrm{Ma}$ ) may reflect the onset of Inverian resetting, possibly the hypothesised high-grade 'early Inverian' (Corfu, 2007).

In the Gruinard block (Loch an Ėisg Brachaidh) samples, two age clusters are prominent, one at ca. $2.75 \mathrm{Ga}$ and one at $2.52-2.5 \mathrm{Ga}$, interpreted to represent the Badcallian and Inverian events, respectively. Although overlapping within uncertainty, populations in the mafic samples (2768-2755 Ma) slightly pre-date those in the leucosome(s) (2740-2725 Ma). Nonetheless, the leucosome ages reproduce well published metamorphic ages of ca. $2730 \mathrm{Ma}$ (Whitehouse et al., 1997; Love et al., 2004) for felsic rocks of the southern parts of the central region (Gruinard block).

The zircon data from the felsic sheet at Cnoc Gorm (sample 04) show much more geochronological similarity to the Scouriemore granulites of the Assynt block (and the Loch an Eisg Brachaidh samples in the Gruinard block) than to the mafic gneisses or leucosomes at Cnoc Gorm. Again, we interpret the older age of ca. $2.75 \mathrm{Ga}$ to represent the Badcallian and the younger age of ca. $2.5 \mathrm{Ga}$ as the Inverian. There is no credible date that corresponds to the Laxfordian event. The differences to the rest of the Cnoc Gorm samples suggests that the main source of the felsic sheet lies in another rock volume. Similarity to the Scouriemore granulites may point to a source either in Scouriemore and the surrounding area or more likely its equivalent at deeper structural levels (underneath the Cnoc Gorm area).

Consequently, during granulite facies (Badcallian) metamorphism, Cnoc Gorm and similar rock packages (presently located in the southern part of the Laxford shear zone) may have been at a shallower structural level compared to areas further south (such as Scouriemore, i.e. the Assynt block). Badcallian metamorphism affecting the deeper crustal levels (equivalents of the Assynt block) would have generated melts with inherited Badcallian zircons that rose to shallower levels at Cnoc Gorm (and environs) that were themselves unaffected by the same high-grade conditions. In this scenario, blocks in the Laxford shear zone represent an intermediate stage between the deep, high-grade Assynt block and the shallower, lowergrade northern region rocks (Rhiconich block) north of Laxford. Both blocks would then represent different crustal levels of the same coherent 


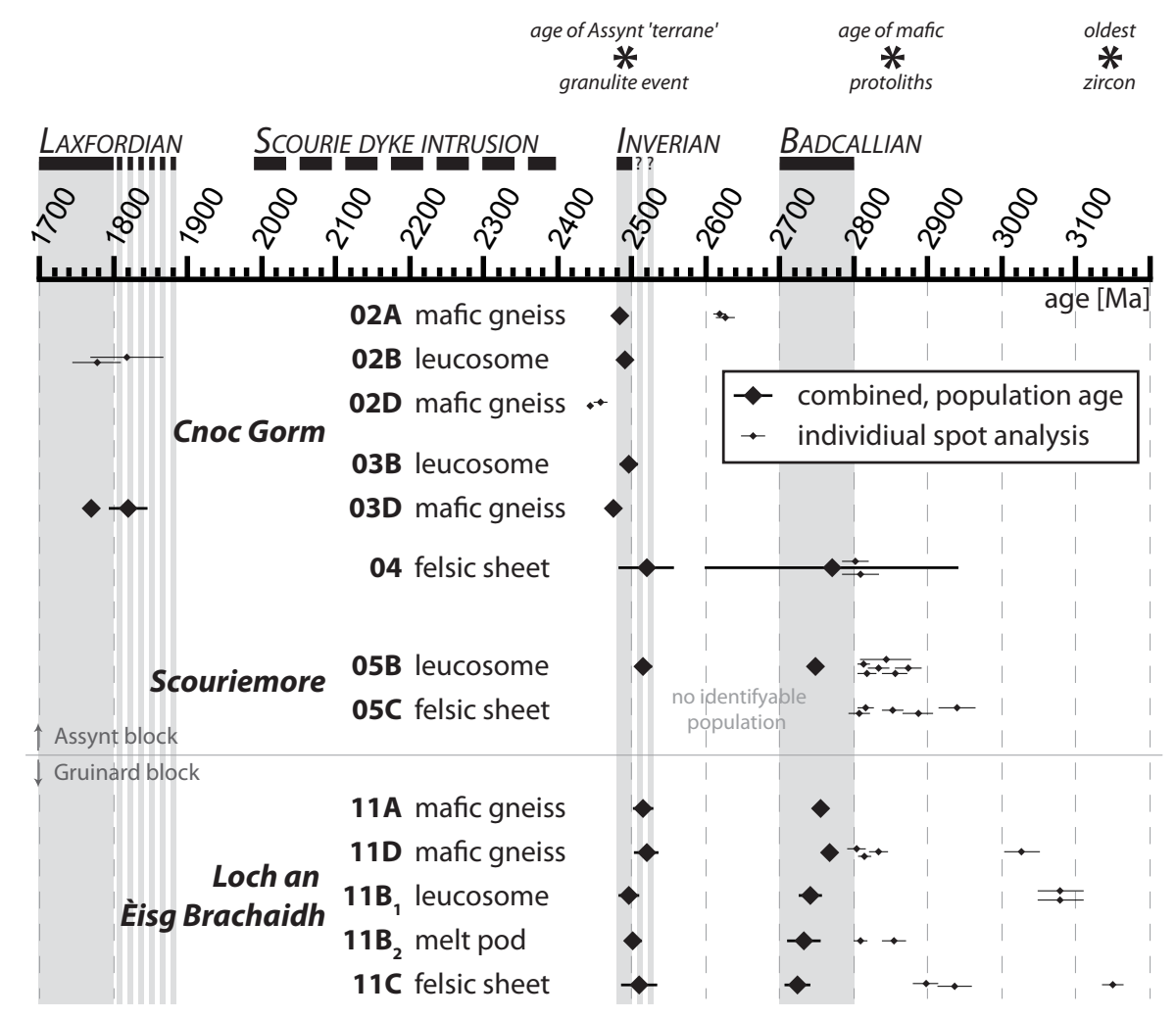

Figure 9: Summary of new zircon geochronology from across the central region, with the established Lewisian events at the top for reference. Where absent, error bars are smaller than the symbol.

crust juxtaposed along a major crustal shear zone (as per earlier interpretations, e.g. Sutton and Watson, 1951; Evans, 1965; Park, 1970), rather than tectonically juxtaposed terranes (Kinny and Friend, 1997; Friend and Kinny, 2001; Love et al., 2004; Kinny et al., 2005; Love et al., 2010).

Several pre-Badcallian ages are found in mafic gneisses of both the Assynt and Gruinard block (e.g. 2833-2800 Ma in sample 11D at Loch an Eisg Brachaidh) and their leucosomes (e.g. dates of 2900-2850 Ma at Scouriemore) as well as their associated felsic sheets (analyses older than $2850 \mathrm{Ma}$ in $05 \mathrm{C}$ and $11 \mathrm{C}$ ). We interpret these as (now partially reset) zircons that formed during crystallisation of the magmatic protoliths. Although zircon abundance in mafic rocks is certainly lower than that in felsic rocks, there are numerous examples of igneous zircons occurring in mafic and metamafic rocks (e.g. Kröner et al., 2006; Scoates and Wall, 2015, and references in the latter). Thus, we consider the recurring ca. $2850 \mathrm{Ma}$ age to represent the magmatic age of the mafic protoliths, in agreement with published Sm-Nd ages of $2943 \mathrm{Ma}$ and $2846 \mathrm{Ma}$ for mafic bodies at Gruinard (Whitehouse et al., 1996).

The pre-Badcallian ages in the felsic sheets were likely inherited from their (mafic gneiss) source rocks. Similar older ages in many TTG gneisses of the Lewisian complex are generally interpreted to date TTG magma emplacement (e.g. Friend and Kinny, 1995). In our interpretation, they do not necessarily date TTG magma emplacement but may represent inheritance from the TTG-meltproducing mafic protolith, analogous to our observation of $2850 \mathrm{Ma}$ inherited ages in the leucosomes.

\subsubsection{Using the $H f-U-P b$ relationship to estimate ages of crust formation}

As many zircons experienced Pb-loss, calculating Hf model ages based on their Hf composition would result in a large spread of apparent mantle-extraction ages. However, extrapolating the population arrays on plots of ${ }^{176} \mathrm{Hf} /{ }^{177} \mathrm{Hf}_{\mathrm{i}}$ vs. ${ }^{207} \mathrm{~Pb} /{ }^{206} \mathrm{~Pb}$ age back to the oldest grains pro- 
vides a more robust initial age for the given $\mathrm{Hf}$ isotopic composition. This assumes that the DM model is representative of the mantle source for the Lewisian crust and that the age of the Hf lock-in is still represented in the dataset, which is reasonable for cases where the array (almost) reaches the DM evolution line.

The array of zircon ages in felsic sheet 05C stretches almost to the DM evolution line and one (inherited) grain (2939 Ma) lies, within uncertainty, on it. Interpreting this as evidence for a DM source for the protolith of this sheet, this array would represent crust formation at ca. 2960-2940 Ma, an age commonly cited as a prevalent protolith (i.e. TTG crystallisation) age in the Lewisian complex (e.g. Friend and Kinny, 1995; Whitehouse et al., 1996; Kinny et al., 2005; Whitehouse and Kemp, 2010; MacDonald et al., 2015).

An even older mantle extraction event is suggested by the arrays and inherited zircon grains in felsic sheets from opposite ends of the central region (i.e. sample 04 from Cnoc Gorm and $11 \mathrm{C}$ from Loch an Eisg Brachaidh, respectively). Extrapolating horizontally back to the DM evolution line (i.e. assuming mainly Pb-loss from a protolith zircon population, analogous to above example) would require a mantle-extraction event $>$ $3000 \mathrm{Ma}$. This extraction does not necessarily imply emplacement of the mafic bodies or the TTGs, but more likely relates to an ultramafic precursor, which was re-melted to produce the mafic magma that formed the mafic bodies (multi-stage crust formation, e.g. Johnson et al., 2014). Three analyses of zircons have ages around $3027 \mathrm{Ma}(2.1 \%$ discordant), $3079 \mathrm{Ma}(11.2 \%$ discordant $)$ and $3149 \mathrm{Ma}$ (8.1\% discordant, $\left.{ }^{176} \mathrm{Hf} /{ }^{177} \mathrm{Hf}_{\mathrm{i}}=0.280750\right)$. The former two would be in agreement with a crustforming event at around $3050 \mathrm{Ma}$, picked up in the Pb-loss arrays of the Lewisian samples with less radiogenic Hf compositions. The latter age would require mantle-extraction, and thereby diversion from the DM evolution, significantly before $3150 \mathrm{Ma}$, as the ${ }^{176} \mathrm{Hf} /{ }^{177} \mathrm{Hf}$ value for that zircon analysis is already less radiogenic than DM at that time $\left({ }^{176} \mathrm{Hf} /{ }^{177} \mathrm{Hf}^{D M}\right.$ at $\left.3150 \mathrm{Ma}=0.28092\right)$. Alternatively, the protoliths to the Lewisian gneisses were not derived from a DM source (cf. Whitehouse and Kemp, 2010).

\subsection{Ti-in-zircon thermometry}

All zircon analyses with pre-Laxfordian ages show similar Ti-in-zircon temperatures of $750-$ $850^{\circ} \mathrm{C}$, which are comparable to findings for zircons from the Scourie area (MacDonald et al., 2015), but significantly lower than the most recent estimates on peak metamorphic temperatures (> $900^{\circ} \mathrm{C}$; Johnson and White, 2011; Johnson et al., 2013; Feisel et al., 2018). However, since most samples lack rutile, these temperatures are minima and are consistent with published estimates. Zircons grown during both the Badcallian and Inverian metamorphic events record similar (peak) temperatures. Notably, our data are coherent within a sample, but also across samples from allegedly different crustal blocks. The younger grains of Laxfordian age mainly record much lower temperatures of $500-600^{\circ} \mathrm{C}$, in good agreement with published estimates for the Laxfordian of ca. $530^{\circ} \mathrm{C}$ (Droop et al., 1999).

\subsection{Implications for the Terrane model}

The terrane model (Kinny et al., 2005; Love et al., 2010), which suggests that the (mainland) Lewisian complex is comprised of separate, faultbounded terranes with distinct tectonothermal histories, is largely based on presence/absence of specific sets of zircon ages (see Section 2.1). The separation of the central region into the Assynt and Gruinard 'terranes' is based on the alleged (c.f. Corfu, 2007) absence of a ca. 2.8-2.7 Ga high-grade metamorphic event within the former as well as the absence of a ca. $2.49 \mathrm{Ga}$ event in the latter (Kinny and Friend, 1997; Love et al., 2004). However, our samples from the Assynt block (Scouriemore) and Gruinard block (Loch an Ėisg Brachaidh) show that both areas experienced a ca. 2750 Ma event and a ca. $2500 \mathrm{Ma}$ event. Minimum Ti-in-zircon temperatures of around $750-850^{\circ} \mathrm{C}$ at all localities suggest that the metamorphic conditions were also broadly uniform throughout the entire central region, consistent with phase equilibrium modelling (Feisel et al., 2018). Consequently, the entire central region experienced a similar metamorphic history and its subdivision into terranes is not warranted.

Hf isotopic compositions are indistinguishable between the putative Assynt and Gruinard blocks, consistent with the inference that their magmatic protoliths were derived from similar (mantle) sources. Based on structural observations, the northern and central region 'terranes' supposedly accreted during the Inverian (ca 2.49 Ga) and 
the suture (the Laxford shear zone) was reactivated during the Laxfordian $(1.8-1.7 \mathrm{Ga}$; Goodenough et al., 2010). Geochronological work over the past decade shows that the central and northern regions (purported Assynt and Rhiconich terranes) have similar protolith ages and may share more of a common (pre-metamorphic) history than previously thought (Goodenough et al., 2013). Our findings are showing similar compatibilities between the central and southern regions: our ages of $2939 \pm 24 \mathrm{Ma}$ from Scouriemore (felsic sheet 05C) and the ca. 3.15-2.9 Ga ages from Loch an Eisg Brachaidh $\left(3079 \pm 30 \mathrm{Ma}\right.$ in leucosome $11 \mathrm{~B}_{1}$, $3149 \pm 14 \mathrm{Ma}$ and $2936 \pm 22 \mathrm{Ma}$ in felsic sheet $11 \mathrm{C}$, and $3027 \pm 24$ Ma mafic gneiss 11D) are comparable to ages from the southern region (Rona block, e.g. Love et al., 2010) indicating that both regions share more of a common history than appreciated previously. Thus, evidence is mounting that contradicts the terrane model, not only for the central region, but probably for the mainland Lewisian complex as a whole.

Our preferred view is that the entirety of the mainland Lewisian complex was one coherent block in the pre-Badcallian with a common (early) history, as suggested by similar protolith ages between all regions. Apparent differences in protolith ages are a result of separate magmatic episodes into the same crustal fragment. Subsequently, the Lewisian complex experienced the Badcallian and Inverian events, and the intrusion of the Scourie dykes. The Palaeoproterozoic Loch Maree group in the southern region, which has been interpreted as an accretionary complex along a collisional suture (Park, 2002), may mark a terrane boundary representing a phase of extension, rifting and re-amalgamation; but its tectonic history is beyond the scope of this study.

The ages for protolith formation and metamorphism of the Lewisian fall within a crucial period in Earth history, when the global geodynamic regime is hypothesised to have transitioned from stagnant lid to plate tectonic settings (e.g. Hawkesworth and Brown, 2018). The geodynamic setting for the Archaean part of the Lewisian history remains open (e.g. Park and Tarney, 1987; Johnson et al., 2016). Our new geochronology does not resolve this directly, but it does provide more refined constraints for assessing the timing and durations of proposed geodynamical models.

\subsection{The case for mafic rocks in zircon studies of high-grade terrains}

Our new approach was to focus on mafic migmatites, rather than TTG gneisses, to disentangle the complex zircon archive of a well-studied but still controversially interpreted high-grade terrain. Careful separation of melanosome and leucosome portions of mafic migmatites, CL imageguided analysis of discrete zircon domains, and the combination of several geochemical tools that zircon offers (U-Pb and Hf isotopes, and Ti-in-zircon thermometry) applied to exactly the same zircon domain provided a data set that appears simpler and more straightforward to interpret than those derived from TTG gneisses over the last 20 years or so, revealing processes and information previously unrecognised.

We attribute this to the fewer and hence simpler processes that may form or affect zircon in mafic rocks. A mafic igneous protolith will only reach zircon saturation close to its final crystallisation (Shao et al., 2018), minimising igneous complexities (e.g. differentiation) and inheritance, as existing zircons in contact with a zircon-undersaturated mafic magma will be resorbed. Consequently, most if not all zircon in a mafic igneous rock will be related to, and hence date, emplacement. Subsequent high-grade metamorphism, especially the breakdown of amphibole, a major host for Zr, can lead to new, prograde growth of zircon (Fraser et al., 1997; Fig. 1) as well as partial melting of mafic gneiss. Any produced melt will be felsic and may inherit pre-existing (igneous) zircon from the mafic gneiss. New zircon (domains) crystallised from the melt as well as any resorption and recrystallisation are a record of the high-grade metamorphic history. Often both generations of zircon can be found in leucosome and the hosting gneiss. Yet, because melt can pool from different sources, their zircon record may differ (cf. the felsic sheet at Cnoc Gorm), underlining the importance to sample both leucosome and melanosome.

\section{Conclusions}

In both blocks of the central region of the Lewisian complex, zircons from mafic migmatites...

record identical Hf isotopic signatures with DMmodel ages for crust formation at ca. $2950 \mathrm{Ma}$ and significantly before ca. $3150 \mathrm{Ma}$; 
give $T_{\text {zirc }}$ that record (peak) temperatures of ca. $800-900{ }^{\circ} \mathrm{C}$, comparable to those estimated from phase equilibrium studies;

have igneous protolith ages older than $3 \mathrm{Ga}$, comparable to the southern region of the complex;

show that both granulite facies Badcallian (ca. 2.7 Ga) and amphibolite facies Inverian (ca. $2.5 \mathrm{Ga}$ ) ages occur throughout the central region;

...suggesting that the central region was always a coherent crustal block. Compared with evidence from other workers, a picture emerges in which the mainland Lewisian complex is, as originally envisaged, a reasonably coherent block of Archaean continental crust in which younger shear zones have juxtaposed different crustal levels that archive their temporally and spatially associated metamorphic conditions.

By focussing on zircon geochemistry in mafic migmatites, we resolve some long-standing controversies in the Lewisian. Our case study therefore illustrates that mafic gneisses and mafic gneisshosted in situ leucosomes may provide a better means to date events in complex gneiss terrains than the volumetrically-dominant zircon-rich felsic lithologies (TTGs).

\section{Acknowledgements}

We thank reviewers Craig Storey and George Guice for their constructive and helpful comments and Wilson Teixeira for the editorial handling. This research was part of SF's PhD studies, and he acknowledges a 600 Year Anniversary Scholarship from the University of St Andrews. An early version of this manuscript benefitted from discussions with Paul Savage and Martin Whitehouse. Analyses were funded through grants with EIMF (IMF545/1114) and NIGL (IP-1473-1114). Fieldwork was funded by NERC grant NE/J021822/1 to PAC. TEJ acknowledges funding from Australian Research Council Discovery Project DP200101104 and support from the State Key Laboratory for Geological Processes and Mineral Resources, China University of Geosciences, Wuhan (Open Fund GPMR201903). PAC acknowledges support from Australian Research Council grant FL160100168. CJH acknowledges support from Leverhulme Trust grants RPG-2015-422 and EM-2017-047\4.

\section{References}

Belousova, E.A., Kostitsyn, Y.A., Griffin, W.L., Begg, G.C., O'Reilly, S.Y., Pearson, N.J., 2010. The growth of the continental crust: Constraints from zircon Hf-isotope data. Lithos 119, $457-466$.

Black, L.P., Williams, I.S., Compston, W., 1986. Four zircon ages from one rock: the history of a 3930 Ma-old granulite from Mount Sones, Enderby Land, Antarctica. Contributions to Mineralogy and Petrology 94, 427-437.

Bowes, D.R., Wright, A.E., Park, R.G., 1964. Layered intrusive rocks in the Lewisian of the North-West Highlands of Scotland. Quarterly Journal of the Geological Society 120, 153-192.

Brown, M., 2014. The contribution of metamorphic petrology to understanding lithosphere evolution and geodynamics. Geoscience Frontiers 5, 553-569.

Cartwright, I., Fitches, W.R., O'Hara, M.J., Barnicoat, A.C., O'Hara, S., 1985. Archaean supracrustal rocks from the Lewisian near Stoer, Sutherland. Scottish Journal of Geology 21, 187-196.

Cawood, P.A., Kröner, A., Pisarevsky, S., 2006. Precambrian plate tectonics: Criteria and evidence. GSA Today 16, 411.

Condie, K.C., 1998. Episodic continental growth and supercontinents: a mantle avalanche connection? Earth and Planetary Science Letters 163, 97-108.

Corfu, F., 2007. Comment to paper: Timing of magmatism and metamorphism in the Gruinard Bay area of the Lewisian gneiss complex: comparison with the Assynt Terrane and implications for terrane accretion by G.J. Love, P.D. Kinny and C.R.L. Friend (Contr Mineral Petrol (2004) 146:620-636). Contributions to Mineralogy and Petrology 153, 483-488.

Corfu, F., Crane, A., Moser, D., Rogers, G., 1998. U-Pb zircon systematics at Gruinard Bay, northwest Scotland: implications for the early orogenic evolution of the Lewisian complex. Contributions to Mineralogy and Petrology 133, 329-345.

Corfu, F., Hanchar, J.M., Hoskin, P.W., Kinny, P., 2003. Atlas of Zircon Textures. Reviews in Mineralogy and Geochemistry 53, 469-500.

Corfu, F., Heaman, L.M., Rogers, G., 1994. Polymetamorphic evolution of the Lewisian complex, NW Scotland, as recorded by $\mathrm{U}-\mathrm{Pb}$ isotopic compositions of zircon, titanite and rutile. Contributions to Mineralogy and Petrology 117, 215-228.

Crowley, Q.G., Key, R., Noble, S.R., 2015. High-precision $\mathrm{U}-\mathrm{Pb}$ dating of complex zircon from the Lewisian Gneiss Complex of Scotland using an incremental CA-ID-TIMS approach. Gondwana Research 27, 1381-1391.

Davies, F.B., 1974. A layered basic complex in the Lewisian, south of Loch Laxford, Sutherland. Journal of the Geological Society 130, 279-284.

Davies, J.H.F.L., Heaman, L.M., 2014. New U-Pb baddeleyite and zircon ages for the Scourie dyke swarm: A long-lived large igneous province with implications for the Paleoproterozoic evolution of NW Scotland. Precambrian Research 249, 180-198.

Dhuime, B., Hawkesworth, C.J., Cawood, P.A., Storey, C.D., 2012. A change in the geodynamics of continental growth 3 billion years ago. Science 335, 1334-1336.

Droop, G.T.R., Fernandes, L.A.D., Shaw, S., 1999. Laxfordian metamorphic conditions of the Palaeoproterozoic 
Loch Maree Group, Lewisian Complex, NW Scotland. Scottish Journal of Geology 35, 31-50.

Evans, C.R., 1965. Geochronology of the Lewisian Basement Near Lochinver, Sutherland. Nature 207, 54-56.

Feisel, Y., White, R.W., Palin, R.M., Johnson, T.E., 2018. New constraints on granulite facies metamorphism and melt production in the Lewisian Complex, northwest Scotland. Journal of Metamorphic Geology 36, 799-819.

Ferry, J.M., Watson, E.B., 2007. New thermodynamic models and revised calibrations for the Ti-in-zircon and $\mathrm{Zr}$ in-rutile thermometers. Contributions to Mineralogy and Petrology 154, 429-437.

Fraser, G., Ellis, D., Eggins, S., 1997. Zirconium abundance in granulite-facies minerals, with implications for zircon geochronology in high-grade rocks. Geology 25, 607-610.

Friend, C.R.L., Kinny, P.D., 1995. New evidence for protolith ages of Lewisian granulites, northwest Scotland. Geology 23, 1027-1030.

Friend, C.R.L., Kinny, P.D., 2001. A reappraisal of the Lewisian Gneiss Complex: geochronological evidence for its tectonic assembly from disparate terranes in the Proterozoic. Contributions to Mineralogy and Petrology 142, 198-218.

Gerdes, A., Zeh, A., 2009. Zircon formation versus zircon alteration - New insights from combined $\mathrm{U}-\mathrm{Pb}$ and $\mathrm{Lu}-$ Hf in-situ LA-ICP-MS analyses, and consequences for the interpretation of Archean zircon from the Central Zone of the Limpopo Belt. Chemical Geology 261, 230-243.

Goodenough, K.M., Crowley, Q.G., Krabbendam, M., Parry, S.F., 2013. New U-Pb age constraints for the Laxford Shear Zone, $\{\mathrm{NW}\}$ Scotland: Evidence for tectonomagmatic processes associated with the formation of a Paleoproterozoic supercontinent. Precambrian Research 233, 1-19.

Goodenough, K.M., Park, R.G., Krabbendam, M., Myers, J.S., Wheeler, J., Loughlin, S.C., Crowley, Q.G., Friend, C.R.L., Beach, A., Kinny, P.D., Graham, R.H., 2010. The Laxford Shear Zone: an end-Archaean terrane boundary? Geological Society, London, Special Publications $335,103-120$.

Griffin, W.L., Wang, X., Jackson, S.E., Pearson, N.J., O'Reilly, S.Y., Xu, X., Zhou, X., 2002. Zircon chemistry and magma mixing, SE China: In-situ analysis of Hf isotopes, Tonglu and Pingtan igneous complexes. Lithos 61, 237-269.

Guice, G.L., McDonald, I., Hughes, H.S., MacDonald, J.M., Faithfull, J.W., 2020. Origin(s) and geodynamic significance of Archean ultramafic-mafic bodies in the mainland Lewisian Gneiss Complex, North Atlantic Craton. Journal of the Geological Society .

Guice, G.L., McDonald, I., Hughes, H.S.R., MacDonald, J.M., Blenkinsop, T.G., Goodenough, K.M., Faithfull, J.W., Gooday, R.J., 2018. Re-evaluating ambiguous age relationships in Archean cratons: Implications for the origin of ultramafic-mafic complexes in the Lewisian Gneiss Complex. Precambrian Research 311, 136-156.

Harley, S.L., Kelly, N.M., Möller, A., 2007. Zircon Behaviour and the Thermal Histories of Mountain Chains. Elements $3,25-30$.

Hawkesworth, C.J., Brown, M., 2018. Earth dynamics and the development of plate tectonics. Philosophical Transactions of the Royal Society A: Mathematical, Physical and Engineering Sciences 376, 20180228.

Johnson, T.E., Brown, M., Goodenough, K.M., Clark, C., Kinny, P.D., White, R.W., 2016. Subduction or sag- duction? Ambiguity in constraining the origin of ultramafic-mafic bodies in the Archean crust of $\{$ NW $\}$ Scotland. Precambrian Research 283, 89-105.

Johnson, T.E., Brown, M., Kaus, B.J.P., VanTongeren, J.A., 2014. Delamination and recycling of Archaean crust caused by gravitational instabilities. Nature Geoscience $7,47-52$.

Johnson, T.E., Fischer, S., White, R.W., 2013. Field and petrographic evidence for partial melting of TTG gneisses from the central region of the mainland Lewisian complex, NW Scotland. Journal of the Geological Society 170, 319326.

Johnson, T.E., Fischer, S., White, R.W., Brown, M., Rollinson, H.R., 2012. Archaean Intracrustal Differentiation from Partial Melting of Metagabbro-Field and Geochemical Evidence from the Central Region of the Lewisian Complex, NW Scotland. Journal of Petrology $53,2115-2138$.

Johnson, T.E., White, R.W., 2011. Phase equilibrium constraints on conditions of granulite-facies metamorphism at Scourie, NW Scotland. Journal of the Geological Society $168,147-158$.

Kelly, N.M., Harley, S.L., 2005. An integrated microtextural and chemical approach to zircon geochronology: refining the Archaean history of the Napier Complex, east Antarctica. Contributions to Mineralogy and Petrology 149, 57-84.

Kinny, P.D., Friend, C.R.L., 1997. U-Pb isotopic evidence for the accretion of different crustal blocks to form the Lewisian Complex of northwest Scotland. Contributions to Mineralogy and Petrology 129, 326-340.

Kinny, P.D., Friend, C.R.L., Love, G.J., 2005. Proposal for a terrane-based nomenclature for the Lewisian Gneiss Complex of NW Scotland. Journal of the Geological Society $162,175-186$

Kröner, A., Compston, W., Williams, I.S., 1989. Growth of early Archaean crust in the Ancient Gneiss Complex of Swaziland as revealed by single zircon dating. Tectonophysics 161, 271-298. Growth of the continental crust.

Kröner, A., Wilde, S.A., Zhao, G.C., O'Brien, P.J., Sun, M., Liu, D.Y., Wan, Y.S., Liu, S.W., Guo, J.H., 2006. Zircon geochronology and metamorphic evolution of mafic dykes in the Hengshan Complex of northern China: Evidence for late Palaeoproterozoic extension and subsequent high-pressure metamorphism in the North China Craton. Precambrian Research 146, 45-67.

Love, G.J., Friend, C.R.L., Kinny, P.D., 2010. Palaeoproterozoic terrane assembly in the Lewisian Gneiss Complex on the Scottish mainland, south of Gruinard Bay: SHRIMP U-Pb zircon evidence. Precambrian Research $183,89-111$.

Love, G.J., Kinny, P.D., Friend, C.R.L., 2004. Timing of magmatism and metamorphism in the Gruinard Bay area of the Lewisian Gneiss Complex: comparisons with the Assynt Terrane and implications for terrane accretion. Contributions to Minera 146, 620-636.

MacDonald, J.M., Goodenough, K.M., 2013. The South Barra shear zone: A composite Inverian-Laxfordian shear zone and possible Terrane boundary in the Lewisian gneiss complex of the Isle of Barra, NW Scotland. Scottish Journal of Geology 49, 93-103.

MacDonald, J.M., Goodenough, K.M., Wheeler, J., Crowley, Q., Harley, S.L., Mariani, E., Tatham, D., 2015. Temperature-time evolution of the Assynt Terrane of the Lewisian Gneiss Complex of Northwest Scotland from zircon U-Pb 
dating and Ti thermometry. Precambrian Research 260, $55-75$.

O'Brien, T.M., Miller, E.L., 2014. Continuous zircon growth during long-lived granulite facies metamorphism: a microtextural, $\mathrm{U}-\mathrm{Pb}, \mathrm{Lu}-\mathrm{Hf}$ and trace element study of Caledonian rocks from the Arctic. Contributions to Mineralogy and Petrology 168, 1071.

Park, R.G., 1970. Observations on Lewisian Chronology. Scottish Journal of Geology 6, 379-399.

Park, R.G., 2002. The Lewisian Geology of Gairloch, NW Scotland. Geological Society Memoir 26, 88p.

Park, R.G., 2005. The Lewisian terrane model: a review. Scottish Journal of Geology 41, 105-118.

Park, R.G., Kinny, P.D., Friend, C.R.L., Love, G.J., 2005. Discussion on a terrane-based nomenclature for the Lewisian Gneiss Complex of NW Scotland (Journal, Vol. 162, 2005, pp. 175-186). Journal of the Geological Society 162, 893-895.

Park, R.G., Tarney, J., 1987. The Lewisian complex: a typical Precambrian high-grade terrain? Geological Society, London, Special Publications 27, 13-25.

Peach, B.N., Horne, J., Gunn, W., Clough, C.T., Hinxman, L.W., Teall, J.J.H., 1907. The Geological Structure of the North West Highlands of Scotland. Memoirs of the Geological Society

Rollinson, H., Gravestock, P., 2012. The trace element geochemistry of clinopyroxenes from pyroxenites in the Lewisian of NW Scotland: insights into light rare earth element mobility during granulite facies metamorphism. Contributions to Mineralogy and Petrology 163, 319-335.

Rollinson, H.R., Windley, B.F., 1980. An archaean granulitegrade tonalite-trondhjemite-granite suite from scourie, NW Scotland: Geochemistry and origin. Contributions to Mineralogy and Petrology 72, 265-281.

Rubatto, D., 2002. Zircon trace element geochemistry: partitioning with garnet and the link between $\mathrm{U}-\mathrm{Pb}$ ages and metamorphism. Chemical Geology 184, 123-138.

Scoates, J.S., Wall, C.J., 2015. Geochronology of Layered Intrusions. Springer Netherlands, Dordrecht. pp. 3-74.

Shao, T., Xia, Y., Ding, X., Cai, Y., Song, M., 2018. Zircon saturation in terrestrial basaltic melts and its geological implications. Solid Earth Sciences 4, 27-42.

Shirey, S.B., Richardson, S.H., 2011. Start of the Wilson Cycle at $3 \mathrm{Ga}$ Shown by Diamonds from Subcontinental Mantle. Science 333, 434-436.

Sills, J.D., Savage, D., Watson, J.V., Windley, B.F., 1982. Layered ultramafic-gabbro bodies in the Lewisian of northwest Scotland: geochemistry and petrogenesis. Earth and Planetary Science Letters 58, 345-360.

Sutton, J., Watson, J., 1951. The pre-Torridonian metamorphic history of the Loch Torridon and Scourie areas in the North-West Highlands, and its bearing on the chronological classification of the Lewisian. Quarterly Journal of the Geological Society 106, 241-307.

Tarney, J., Weaver, B.L., 1987. Geochemistry of the Scourian complex: petrogenesis and tectonic models. Geological Society, London, Special Publications 27, 45-56.

Taylor, R.J., Johnson, T.E., Clark, C., Harrison, R.J., 2020. Persistence of melt-bearing Archean lower crust for $>200$ m.y.-An example from the Lewisian Complex, northwest Scotland. Geology 48, 221-225.

Valley, J.W., Lackey, J.S., Cavosie, A.J., Clechenko, C.C., Spicuzza, M.J., Basei, M.A.S., Bindeman, I.N., Ferreira, V.P., Sial, A.N., King, E.M., Peck, W.H., Sinha, A.K., Wei, C.S., 2005. 4.4 billion years of crustal maturation: oxygen isotope ratios of magmatic zircon. Contributions to Mineralogy and Petrology 150, 561-580.

Wheeler, J., Park, R.G., Rollinson, H.R., Beach, A., 2010. The Lewisian Complex: insights into deep crustal evolution. Geological Society, London, Special Publications $335,51-79$.

Whitehouse, M.J., Claesson, S., Sunde, T., Vestin, J., 1997. Ion microprobe $\mathrm{U}-\mathrm{Pb}$ zircon geochronology and correlation of Archaean gneisses from the Lewisian Complex of Gruinard Bay, northwestern Scotland. Geochimica et Cosmochimica Acta 61, 4429-4438.

Whitehouse, M.J., Fowler, M.B., Friend, C.R.L., 1996. Conflicting mineral and whole-rock isochron ages from the Late-Archaean Lewisian complex of northwestern Scotland: Implications for geochronology in polymetamorphic high-grade terrains. Geochimica et Cosmochimica Acta 60, 3085-3102.

Whitehouse, M.J., Kamber, B.S., Moorbath, S., 1999. Age significance of $\mathrm{U}-\mathrm{Th}-\mathrm{Pb}$ zircon data from early Archaean rocks of west Greenland - a reassessment based on combined ion-microprobe and imaging studies. Chemical Geology 160, 201-224.

Whitehouse, M.J., Kemp, A.I.S., 2010. On the difficulty of assigning crustal residence, magmatic protolith and metamorphic ages to Lewisian granulites: constraints from combined in situ U-Pb and Lu-Hf isotopes. Geological Society, London, Special Publications 335, 81-101.

Wilde, S.A., Valley, J.W., Peck, W.H., Graham, C.M., 2001. Evidence from detrital zircons for the existence of continental crust and oceans on the Earth 4.4 Gyr ago. Nature 409, 175-178.

Zhu, Z.K., O'Nions, R.K., Belshaw, N.S., Gibb, A.J., 1997. Lewisian crustal history from in situ SIMS mineral chronometry and related metamorphic textures. Chemical Geology 136, 205-218.

Zirkler, A., Johnson, T.E., White, R.W., Zack, T., 2012. Polymetamorphism in the mainland Lewisian complex, NW Scotland - phase equilibria and geochronological constraints from the Cnoc an t'Sidhean suite. Journal of Metamorphic Geology 30, 865-885. 